\title{
On the political economy of the financial crisis and bailout of 2008-2009
}

\author{
Roger D. Congleton
}

Received: 24 June 2009 / Accepted: 26 June 2009 / Published online: 14 July 2009

(C) Springer Science+Business Media, LLC 2009

\begin{abstract}
U.S. policies to promote home ownership and other banking regulatory decisions helped to create a highly leveraged international market for mortgage-based securities. Declines in the price of housing, consequently, had major effects on the balance sheets and portfolios of financial institutions throughout the world.

The political response to the financial crisis has been rapid and large. In general, differences in the effectiveness of government policies show the advantage of standing institutions at crisis management relative to innovative legislation.
\end{abstract}

Keywords Political economy $\cdot$ Crisis management $\cdot$ Regulatory failure $\cdot$ Financial markets · Housing markets · Credit markets $\cdot$ Asset bubbles $\cdot$ Public choice

JEL Classification D72 $\cdot \mathrm{D} 73 \cdot \mathrm{D} 8 \cdot \mathrm{K} 2$

\section{Introduction: Housing prices, bubbles, and the recession of 2008}

Given that the median family's wealth in the United States consists largely of equity in its home, it is not surprising that all levels of governments within the United States adopt policies that tend to increase the value of existing homes. The most obvious of these policies is the income-tax deductibility of interest paid on home mortgages, which tends to increase the demand for mortgages and has been part of the federal tax code since it was first adopted in 1913. Other long-standing policies include recorded deeds, zoning, and building codes, which tend to increase the value of existing housing by reducing various kinds of risk and somewhat discouraging new construction. Mortgages themselves are encouraged further by through various regulations and other policies that increase the supply of mortgages. These policies, together with rising family incomes, have caused home prices to rise fairly steadily since the end of the Great Depression. The median value of a single family home rose from

R.D. Congleton $(\bowtie)$

Center for Study of Public Choice, George Mason University, Fairfax VA 22030, USA

e-mail: congleto@gmu.edu 


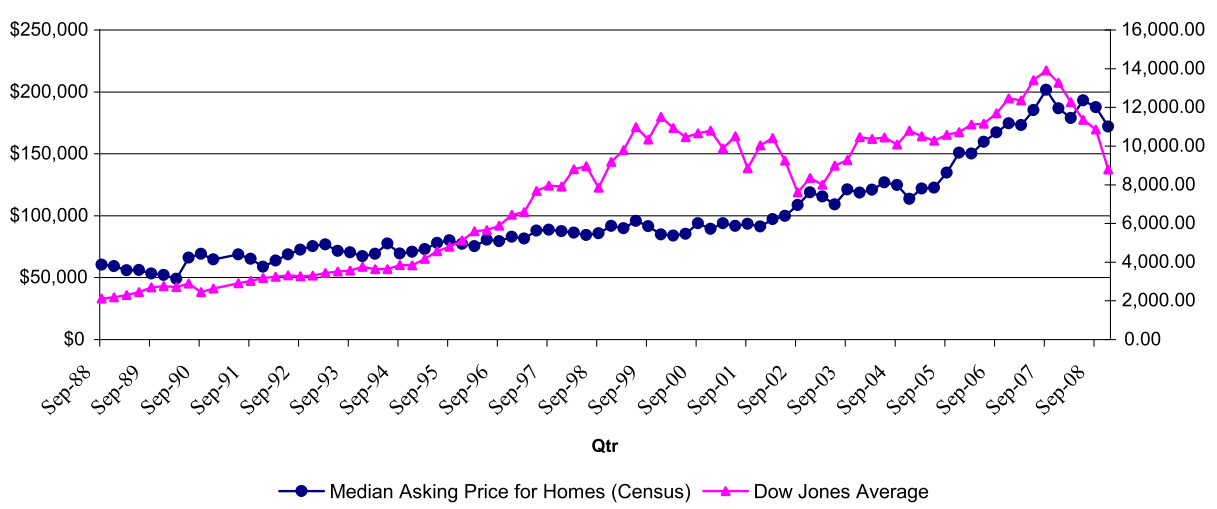

Fig. 1 Housing and stock prices quarterly, 1988-2008

$\$ 30,600$ in 1940 to $\$ 119,600$ in 2000 (in 2000 dollars). ${ }^{1}$ This more or less steady rise in home values continued into the twenty-first century and, indeed, accelerated. ${ }^{2}$

Home prices are economically important, because homes are by far the largest component of personal wealth for most U.S. households and a major component of national wealth. For example, in 2004 personal portfolios of private homes and equities were worth $\$ 19.1$ and $\$ 3.7$ trillion (net), respectively, out of a total of $\$ 50.2$ trillion of assets held by households in the United States. About two-thirds of the net wealth owned by the lowest $95 \%$ of the distribution of wealth owners is equity in homes (Kennickell 2006: table 11a). Microeconomic theory implies that personal wealth is a major determinant of personal spending and investment. Macroeconomics implies that consumption and investments are major determinants of national income and economic growth.

Figure 1 plots time series for median home values and the Down Jones Average from 1988 through 2008. The graphs show that home prices and stock prices both rose at an unusually brisk pace from early 2004 until 2007, and then fell at unusually brisk rates. Real median house prices rose 50\% in value and the Dow Jones Average rose 34\% in the 2.5 years running from the first quarter of 2004 through the third quarter of 2007, well above their average annual real growth rates (2.75\%/year and 4.42\%/year) from 1950 to 2000 . The effect of several trillion dollars in new wealth generated by the rapid increase in housing values and stock prices helped increase economic growth rates in that period by increasing consumer spending and by providing an asset base for investment loans. The subsequent $17 \%$ fall in housing prices and $37 \%$ fall in stock prices through the end of 2008 reduced personal wealth and increased uncertainty, which, in turn, have produced a relatively deep recession, with estimated real gross domestic product (RGDP) at the end of 2008 falling

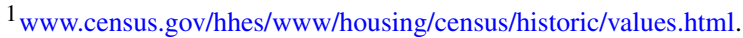

${ }^{2}$ The census data report median house prices using prices listed for properties on the market, rather than sales prices. This introduces an upward bias in all of the numbers. For the purposes of this paper, it is assumed that asking and sales prices have a stable relationship. The widely used Case-Shiller index uses sales prices, but from a narrower base of 20 metropolitan areas to estimate national house prices. It shows similar acceleration in house prices. End-of-quarter values for the Dow Jones Average were downloaded from the Dow Jones website (www.djaverages.com/).
} 
about a half of one percent below that of the third quarter of 2007 and nearly $1.5 \%$ below its quarterly peak earlier in $2008 .^{3}$

In microeconomic terms, a decrease in personal wealth caused consumers to reduce their expenditures on normal and superior goods, which reduced cash flows for firms selling such goods and services and for suppliers of intermediate goods. The demand for inferior goods increased, but not as much as the demand for superior and normal goods decreased. With reduced demand for inputs of all sorts, employees have been fired faster than they have been rehired elsewhere. Unemployment consequently rose from 4.7 to $7.2 \%$ during 20072008, which is the highest U.S. unemployment rate since January 1993. Most forecasters anticipate that unemployment rates in 2009 will continue to climb, because the wealth effects of punctured asset-price bubbles are being reinforced by tougher standards for credit.

It was the collapse of prices in another less familiar asset market, however, that led Secretary of the Treasury Paulson to warn Congress in September of 2008 that another Great Depression might occur in 2009 unless extraordinary steps were taken immediately by the U.S. government. In the past few decades, a new, very large market for mortgage-backed securities had emerged. These and similar credit-backed securities are not held by many private investors directly, but they play important roles in the portfolios of banks, finance firms, insurance companies, pension funds, and sovereign wealth funds. Their values fell rapidly partly because of greater uncertainty about the future household income and housing prices that ultimately back such securities, and partly because the risks associated with those assets were misjudged and mispriced. As a consequence, the balance sheets of a wide range of companies have lost much of their capital base. ${ }^{4}$ Whether Paulson's warning was disproportionate to the system-wide risks or not, it is clear that the "piercing" of the real estate, stock market, and mortgage-backed security "bubbles" had important effects on the real economy-even though the physical assets of the real economy (organizations, labor, land, and capital) remained in place. It is also clear that Paulson's warning has induced major changes in fiscal and monetary policies.

This paper investigates the role that government policies played in the expansion and collapse of the housing and financial bubbles of the early twenty-first century. The analysis and historical narrative focus for the most part on the housing market and extend as necessary to financial and banking regulations. The analysis concludes that the housing and stock bubbles were generated largely by market forces, rather than by government policies, although government policies and institutions played significant roles. The risk of future financial crises can, therefore, be reduced through changes in government policies and institutions, although it is unlikely to be eliminated.

\footnotetext{
${ }^{3}$ Data on economic indicators are from information assembled from the St. Louis Federal Reserve's Alfred ${ }^{\circledR}$ and Census data websites, unless otherwise mentioned. In addition to the references included at the end of the paper, the narrative is also grounded in dozens of hours spent watching Congressional testimony (on C-Span). The text of major pieces of legislation referred to below are available on line from a variety of sources. Only the principal references are listed at the end of the paper. Minor references and data sources are referenced in the text.

${ }^{4}$ Most publicly traded firms are required to meet capital requirements. The assets of firms whose capital bases included mortgage-backed securities were in many cases smaller than allowed by law in 2007 and 2008. Indeed, many firms in the finance sector were now bankrupt, at least based on mark-to-market accounting rules. The market value of their assets and (net) cash flows were smaller than their debts.
} 


\section{Government provided supply-side support for mortgage markets}

In the "good old days," mortgages were held by the banks that made loans; so if there were any problems with mortgages, they tended to be concentrated in the banks located in regions with declining housing prices, unemployment, and net out-migration. This changed in 1932 and 1938, when President Herbert Hoover founded the Federal Home Loan Banks (FHLBs) and his successor, Franklin Delano Roosevelt founded the Federal National Mortgage Association (FNMA or "Fannie Mae"). Their purpose was to add liquidity to the home mortgage market in order to facilitate home sales and reduce bank failures. The FHLBs initially provided short-term loans to savings and loan (S\&L) institutions ("thrifts"), whose liquidity was reduced by bank runs and mortgage defaults at the beginning of the Great Depression. ${ }^{5}$ Fannie Mae purchased and held mortgages from banks and also insured mortgages, which allowed lenders to create more mortgages at lower prices because the risks associated with mortgage defaults were shifted to Fannie Mae. The Housing Act of 1949 authorized the Federal Housing Administration (FHA) to insure home mortgages and to construct 810,000 public housing units. ${ }^{6}$

Between the various housing policies of the federal and state governments and the rising incomes associated with renewed economic growth after World War II, home ownership rates increased from $43.6 \%$ in 1940 to $61.9 \%$ in $1960 .^{7}$ Evidently, the $61.9 \%$ ownership rate of 1960 was not "enough," and the federal government took additional steps to encourage home ownership. In 1968, Fannie Mae was privatized, which meant that a new management company was created to oversee the large portfolio of mortgages Fannie Mae had already assembled. In 1970, the Federal Home Loan Mortgage Corporation (FHLMC or "Freddie Mac") was established to make loans and loan guarantees and to create a market for mortgage-backed securities. Freddie Mac pooled the mortgages it purchased and sold mortgage-backed securities to investors on the open market. This essentially created a new financial market in mortgage-backed securities, which further increased the supply of mortgages by introducing a more indirect means of mortgage finance. The guarantees and pooling of mortgages by Freddie reduced the risk associated with the purchase of mortgage-backed securities and induced more investors to hold them. Again, the purpose

\footnotetext{
${ }^{5}$ In effect, the FHLB was to function as the reserve bank for the S\&Ls that were outside of the Federal Reserve System. It was capitalized by the federal government, but was for the most part financed privately through services provided to member institutions. Among those services, the FHLB gradually assembled a large portfolio of mortgages and mortgage-backed securities, although a somewhat smaller one than the one assembled by Fannie Mae and by the Federal Home Loan Mortgage Corporation (FHLMC or Freddie Mac) (Mason 2004).

${ }^{6}$ Federal housing programs created during the early post-war period are discussed in Mason (2004: 153162). Mason also discusses how lobbyists for savings and loans attempted to affect the extent of taxation, regulation, and support for housing for much of U.S. history. One striking example occurred in 1950, when S\&Ls became subject to federal taxes for the first time, but only if their reserves rose to $12 \%$ of assets. In this manner, tax policy encouraged S\&Ls to hold relatively small capital reserves, increasing their fragility during difficult times (Mason 2004:155).

${ }^{7}$ Home ownership rates fell from $47.8 \%$ to $43.6 \%$ during the decade of the Great Depression. Prior to the Great Depression, home ownership had fluctuated between $45 \%$ and $48 \%$, rising somewhat during the Roaring Twenties. Home ownership varied significantly among the states during the early twentieth century. For example, in $1900,80 \%$ of the residents in North Dakota and $71.2 \%$ of those in South Dakota lived in their own homes, whereas only $28 \%$ in Rhode Island and $30.6 \%$ in South Carolina did so. The variance among the states declined during the twentieth century, while the average increased. Recent data show that Minnesota, at $74.6 \%$, had the most, while Hawaii, at $56.5 \%$, had the fewest homeowners. (Historical census of housing tables, 2004).
} 
was to increase the demand for mortgages, which would encourage banks to make more loans for housing. ${ }^{8}$ Fanny Mae began originating its own mortgage-backed securities at approximately the same time (Cowan 2003).

\subsection{Fannie, Freddie and the market for mortgage-backed securities}

After initial periods of federal support, all of these government-sponsored enterprises (GSEs) became more or less private entities. None had formal backing from the U.S. Government, although they were managed partly through government appointees and subject to different forms of government oversight than other financial firms. Most investors consequently believed that, if need be, U.S. taxpayers would back up the GSEs after they were "privatized," which proved to be correct in September 2008. The implicit backing of taxpayers allowed the FHLB, Fannie Mae, and Freddie Mac to borrow money at rates lower than other banks (about $0.4 \%$ less, according to Congressional Budget Office estimates). The GSEs also faced somewhat different regulatory constraints than ordinary investment banks. They were, for example, exempt from most state taxes and regulations, which provided an implicit subsidy of approximately a billion dollars. ${ }^{9}$

These implicit subsidies to housing were not on the federal government's balance sheets, nor were the risks associated with the implicit guarantees of the federal government. Consequently, no fees were charged for this insurance and no insurance reserves were accumulated. This further increased Fannie's and Freddie's profits, which were passed onto their shareholders.

The loans purchased and resold by Fannie Mae and Freddie Mac initially met more or less ordinary standards for mortgages and had an upper limit, although both constraints were relaxed during the past two decades. ${ }^{10}$ After 1992 Fannie Mae and Freddie Mac were encouraged to purchase "affordable" mortgages from banks, which essentially meant mortgages that did not pass the usual creditworthiness requirement for loans. In terms of the Federal Housing Enterprises Financial Safety and Soundness Act of 1992:

(7) The Federal National Mortgage Association and the Federal Home Loan Mortgage Corporation have an affirmative obligation to facilitate the financing of affordable housing for low-and moderate-income families in a manner consistent with their overall public purposes, while maintaining a strong financial condition and a reasonable economic return.

The same 1992 law assigned oversight responsibility for the GSEs to a unit of the U.S. Department of Housing and Urban Development (HUD). ${ }^{11}$ With "affordable housing" in

\footnotetext{
${ }^{8}$ The Congressional Budget Office estimated that in 2000, about $22.7 \%$ of fixed-rate single-family mortgages were held by Fannie Mae and Freddie Mac, although they had issued about $71 \%$ of all mortgage-backed securities (Crippen 2001a: 5).

${ }^{9}$ The Congressional Budget Office has estimated that the present value of the implicit subsidies between 1995 and 2000 varied from $\$ 6.8$ to $\$ 15.6$ billion. The interest savings alone varied from $\$ 3.7$ to $\$ 10.2$ billion, while the regulatory and tax advantages varied from $\$ 0.7$ to $\$ 1.2$ billion. The remainder of the implicit subsidy was through implicit insurance (and therefore higher prices) for the GSE issues of mortgage-backed securities (Crippen 2001: Table 1).

${ }^{10}$ For example, the maximum mortgage on a single-family home that Fannie Mae would purchase in 1980 was $\$ 140,625$. This upper bound rose every year until it reached $\$ 625,500$ in 2009 , although the Economic Stimulus Act of 2008 allows Fannie Mae to purchase loans 125\% larger than that limit: \$729,750 in high-cost areas. (See www.fanniemae.com/aboutfm/pdf/historicalloanlimits.pdf.)

${ }^{11}$ The Federal Housing Enterprises Financial Safety and Soundness Act of 1992 created the Office of Federal Housing Enterprise Oversight (OFHEO) as a department of HUD. It was given the responsibility of oversee-
} 
mind, HUD established annual targets for extending loans to "underserved areas" and for "low- and moderate-income housing." These goals for Fannie Mae and Freddie Mac were increased gradually, from $30 \%$ in 1993 to $55 \%$ in 2007. ${ }^{12}$ Both Fannie Mae and Freddie Mac normally met or exceeded their targets, and so the affordable housing goals helped to create a new market in "sub-prime" (e.g., sub-standard) mortgages and mortgage-backed securities. Encouragement to extend such "sub-prime" loans continued to be received from HUD administrators under Presidents Clinton and George W. Bush, in part because this allowed housing to be subsidized without the need for additional congressional approval or funds.

It bears noting that bundling and insuring mortgages can be highly profitable, especially when home prices are rising. To see this, suppose that a $100 \%$ mortgage is issued on a $\$ 250,000$ house. Annual payments on a 30-year mortgage at $6 \%$ interest are a bit more than $\$ 18,000 /$ year. The $6 \%$ interest rate includes a risk premium of $1-2 \%$, because some borrowers ultimately will default and the house will have to be reclaimed through court proceedings, during which no income is earned on the loan. Suppose that a bundler-insurer can lower the risk premium by $1 \%$. The "discount rate" is now $5 \%$, rather than $6 \%$, and the cash flow of the mortgage is now worth more than the house, a bit more than $\$ 275,000$. The greater the reduction in risk premium achieved by the "bundler-insurer," the greater is the "profit" (as long as one does not actually pay much out on the insurance provided). If the risk premium falls by $2 \%$, the discount rate becomes $4 \%$ and the value of the mortgage's cash flow becomes a bit more than $\$ 310,000$, more than $25 \%$ greater than the value of the house standing behind the mortgage. Because of this risk-premium effect, bundling subprime mortgages can be much more profitable than bundling prime mortgages, because risks can be reduced further through diversification, at least in principle, especially when default levels are below average.

A variety of methods can be used to reduce the statistical risk associated with relatively risky mortgages. Sub-prime mortgages can be pooled, and several securities can be created from that pool. To see how this can be done, suppose that the promised payments of the subprime mortgage-payers will produce $\$ 10$ million a year of income when everyone in the pool pays on time. One security can be backed with the first $\$ 5$ million of income from that pool and another with the remainder. The first security has almost no risk associated with it, because it is unlikely (at least before 2008) that $50 \%$ of a pool of sub-prime mortgage payers would default. The second, subordinate security would be much riskier. However, a safer third security could be created by pooling subordinate claims from similar mortgage pools. The mortgage payments into that subordinate pool could be divided further to create securities with more or less senior claims on expected revenues, and so forth. In this manner, composite securities (derivatives) can be created from pools of risky assets that are themselves, at least statistically, of relatively low risk. Risks can be reduced further by providing insurance of various kinds. ${ }^{13}$

In this manner, new wealth is created by producing less risky assets, which can be sold to alternative investors or offered as collateral for different loans, which may be used to

ing financial aspects of Fannie Mae, Freddie Mac, and the Federal Home Loan Bank Finance Corporation. It monitored capital levels, financial disclosure and internal controls. A proposal to make OFHEO an independent agency was made in 2005, but the legislation was not adopted. OFHEO is funded through fees collected from Fannie Mae and Freddie Mac.

${ }^{12}$ See Fannie Mae (2007) Annual Report (pp. 4-8 and 14-15).

${ }^{13}$ See Mason and Rosner (2007) for an overview of the structure of mortgage-backed securities and other collateralized debt obligations. 
purchase other securities. The new assets can also be used as a means of payment as, for example, mortgage-backed securities were routinely used to buy mortgages from banks.

The creation of these new financial instruments created a new housing-based supply of credit separate from the usual money-based credit system of conventional banking.

The mortgage-backed securities (MBSs) created by Fannie Mae and Freddie Mac were used to purchase mortgages from banks, which often held them as capital (instead of their own mortgages) because Fannie and Freddie's MBSs were considered to have lower risks associated with them. ${ }^{14}$ The mortgage-backed securities created by Fannie and Freddie nominally are "insured" by them, which "guarantees" to purchasers that both principal and interest will be paid regardless of whether those who financed their house purchases continued their mortgage payments or not.

Fannie Mae and Freddie Mac had essentially created the market in mortgages and mortgage-backed securities and remained major players in those markets, even as private firms of various kinds entered the market. Fannie Mae and Freddie Mac together issued more than $70 \%$ of mortgage-backed securities in 2000 and $60 \%$ of mortgage-backed securities in $2002 .{ }^{15}$ Indeed, in the summer of 2008, the newly created Federal Housing Finance Agency reported that

as of June 2008, the combined debt and (MBS) obligations of these GSEs totaled $\$ 6.6$ trillion, exceeding the total publicly held debt of the U.S. [government] by $\$ 1.3$ trillion. The GSEs also purchased or guaranteed $84 \%$ of new mortgages.

Fannie and Freddie remained major players in the mortgage market even as they approached bankruptcy in 2007-2008. ${ }^{16}$

\subsection{Not just Fannie and Freddie}

The demand for safe assets was high and rising during much of this period, as the babyboom generation saved for retirement in $401 \mathrm{k}$ accounts and holders of dollars generated by large and growing U.S. trade deficits sought profitable safe places to invest their dollars. Competition in both the mortgage origination and bundling markets intensified.

Default rates on mortgages had been low for many years, because rising home values allowed mortgages to be refinanced to solve cash-flow problems that naturally occur for a subset of home buyers each year (especially those taking out sub-prime mortgages). As long as delinquency rates were below their long-run average, reserves could also be below prudent levels, which increased profits and bonuses. The latter possibility implied that employees had strong personal interests in making optimistic assumptions about future default rates and trends in housing values. As long as the upward trend in home values continued, there was money to be made. The rapid rise in real estate prices consequently induced speculators to enter the market as purchasers of houses, mortgage bundlers, and purchasers of

\footnotetext{
${ }^{14}$ See, for example, (Fannie Mae 2007) Annual Report (p. 5), which describes the typical issue of mortgagebacked securities to banks in exchange for mortgages. The mortgages that are held in trusts to support the MBSs are sometimes accounted for as MBSs, rather than as mortgages in some datasets on mortgage holdings.

${ }^{15}$ See Crippen (2001a, 2001b) or The Economist (July 18, 2002).

${ }^{16}$ These totals include the smaller loan portfolios of the Federal Home Loan Banks, as well as Fannie Mae and Freddie Mac. The Federal Housing Finance Agency is a new regulatory agency for Fannie Mae, Freddie Mac, and the FHLBs. It was created on July 30, 2008 from the combined the staffs of the Office of Federal Housing Enterprise, the Federal Housing Finance Board, and the GSE mission office at HUD. See www.fhfa.gov/Default.aspx?Page=4.
} 
sub-prime loans. Of course, the value-added by bundling mortgages depended entirely on the estimated probability of default and the reliability of the insurance assumed by those who assess the "quality" of the new assets. These risk assessments were evidently overly optimistic during the boom years from 2000-2007.

The supply of funds for credit in general and mortgage-backed securities in particular was also increased by a series of banking regulatory reforms that allowed the emergence of large national and international banking/insurance conglomerates. For example, the RiegleNeal Interstate Banking Act of 1994 allowed holding companies to own banks in several states and allowed the merger of banks from different states. The Gramm-Leach-Bliley Act of 1999 effectively repealed the Glass-Steagall Act of 1935 by allowing holding companies to own insurance and security companies as well as banks. ${ }^{17}$ In 2004 a special ruling of the U.S. Securities and Exchange Commission (SEC) allowed the five largest investment banks in the United States to reduce their capital reserves. This SEC ruling permitted those already less regulated "banks" to become far more highly leveraged enterprises, which allowed them to increase the pool of assets under their control. Within a few years, those five privileged banks controlled $\$ 4$ trillion in financial assets, but with relatively little (net) equity. ${ }^{18}$

Another change in regulation that (initially) increased the supply of loanable funds was the more widespread use of "mark-to-market" accounting rules that followed the adoption of the Sarbanes-Oxley Act of 2002. The revised accounting guidelines required more capital assets to be valued at their current market prices. ${ }^{19}$ During times of rising financial asset prices, a firm's capital base increases under mark-to-market rules, which allows some of its capital to be sold to others or to be used as collateral for new loans, while staying within required capital-to-debt ratios. Mark-to-market rules, of course, do not force new borrowing on the part of firms. "Leverage," however, increases rates of return as long as asset values continue to appreciate, and competition among firms (and employees) tends to favor those

\footnotetext{
${ }^{17}$ Summaries of major changes in banking regulations are available at the Federal Deposit Insurance Corporation's (FDIC's) website: www.fdic.gov/regulations/laws/important/index.html.

${ }^{18}$ Labaton (2008, Oct 3) reports that a change in the capital requirements (the net capital rule) for the five largest investment banks allowed leverage ratios far greater than in the past. This rule change increased potential profits, but also made them into more fragile enterprises. As stated by Labaton, as "Bear Stearns faced imminent collapse in early March [of 2008], Christopher Cox [chairman of the SEC] was told by his staff that Bear Stearns had $\$ 17$ billion in cash and other assets-more than enough to weather the storm. Drained of most of its cash three days later, Bear Stearns was forced into a hastily arranged marriage with J.P. Morgan Chase-backed by a $\$ 29$ billion taxpayer dowry. Within six months, other lions of Wall Street would also either disappear or transform themselves to survive the financial maelstrom-Merrill Lynch sold itself to Bank of America, Lehman Brothers filed for bankruptcy protection, and Goldman Sachs and Morgan Stanley converted to commercial banks."

${ }^{19}$ Financial firms use a variety of methods for determining the values of their capital bases: historical values, mark-to-market, and "modeled" values. Mark-to-market is a long-standing accounting principle that uses current market prices to determine the values of risky assets. For example, the value of personal stock portfolios are always assessed at current market prices. The Sarbanes-Oxley Act did not create or mandate mark-tomarket accounting. Rather, it encouraged the use of more conservative and transparent accounting practices. To do so, it created the Public Company Accounting Oversight Board (PCAOB) to standardize methods for computing the "fair value" of assets, and PCAOB encouraged publicly traded firms to use market values to determine an asset's "fair value," especially for assets that are routinely traded. Similar guidelines were subsequently adopted by the private Financial Accounting Standards Board (FASB), which clarified its principles for determining "fair value" in its statement 157 issued in 2007. (An overview of the guidelines is available at www.fasb.org/st/summary/stsum157.shtml.) Determination of the "fair value" of a risky asset is a non-trivial question for accountants and economists, and the PCAOB, FASB, and the IRS have changed how fair value should be calculated numerous times during their histories. (The FASB is a private organization established in 1973 by the Financial Accounting Foundation.)
} 
earning the highest returns. Expanded use of mark-to-market valuation was, thus, broadly supported by firms in financial markets - until the asset bubbles burst.

The risks associated with the broad range of mortgage-backed securities issued were assessed by private companies, such as Standard and Poor's, Moody's and Fitch. Perhaps surprisingly, AAA (low-risk) ratings could be obtained for nearly every combination of the new financial assets by adding a bit of insurance to the mix, which often was arranged through other complex securities. ${ }^{20}$

The pool of mortgages and mortgage-backed securities increased rapidly during the late 1990s and early 2000s because of government policies that affected Fannie, Freddie, and financial regulations. U.S. trade deficits further increased in the pool of funds searching for safe assets. Consequently, mortgage-backed and other credit-backed securities became significant elements in investment portfolios and capital reserves of investors, firms, nonprofits, and governments worldwide.

\section{Voters, interest groups, regulators, and the risk of mortgage default}

The politics of government interventions in the mortgage market differ from interventions in most other markets, because of the size of the market and its relative importance to ordinary voters and investors throughout the world. For example, the president of the United States selects about a third of Fannie Mae's and Freddie Mac's boards of directors (five of 17 and five of 18 , respectively); the rest are elected by stockholders. ${ }^{21}$ The size and importance of these GSEs have also produced an unusual amount of political and media attention. The archives of The New York Times include nearly 10,000 pieces reporting on the regulation of Fannie Mae; The Financial Times (of London) includes more than 500 articles on similar topics in the past five years. Nonetheless, government intervention on the supply side of the mortgage market has never risen to the point of being a central issue in national election campaigns; so, the details of that intervention are normally worked out within Congress and HUD, with the assistance of various lobbying groups.

Among the most prominent lobbyists are the GSEs themselves and organizations representing commercial banks and realtor groups, which have roughly opposing interests in the extent to which these GSEs should be subject to more or less regulation, receive more or less implicit support from taxpayer guarantees, or both. ${ }^{22}$

Before the housing bubble burst in 2006-2007, it could be argued that the various housing policies of the federal government had broadly advanced the interests of the median voter (who is a home owner) at the same time that it balanced the interests of an assortment

\footnotetext{
${ }^{20}$ To make obtaining an AAA rating a bit easier for the security issuers, the rating companies had released their metrics for risk assessments. This led to the creation of many complex securities that only just met AAA standards, because this would maximize the profits that could be squeezed from a given pool of mortgages. This "optimization" implied that even small changes in risk would change the credit ratings of most mortgagebacked securities, but only when (and if) the rating agencies updated their ratings of past issues.

${ }^{21}$ Fannie Mae's (2007) annual report (p. 40) mentions that the terms of the five presidential appointees had expired in 2004, but no replacements had either been nominated or confirmed through 2007.

${ }^{22}$ For example, the National Association of Realtors' website includes the statement, "We support the federal government's actions and authorization to help ensure the ability of Fannie Mae and Freddie Mac to promote the availability of home mortgage credit during a period of stress in the financial markets. Fannie and Freddie play a central role in our housing finance system, and we agree that they must continue to do so as we work through the current housing correction" (July 14, 2008 news release. www.realtor.org/press_room/news_ releases/2008/07/nar_statement_on_importance_of_fannie_and_freddie.)
} 


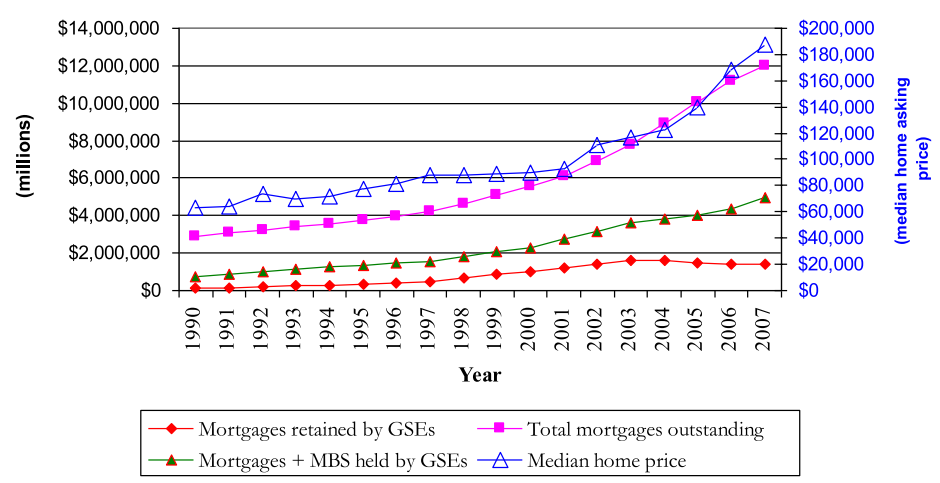

Fig. 2 US mortgage market

of economic interest groups. Median house prices rose steadily, with only minor downturns, during the entire postwar period (see Fig. 2). The mortgage resale market had become more complex, as more and more sophisticated methods were devised to pool revenues from mortgages and mortgage-backed securities. Many experts, however, believed that the new securities markets increased liquidity and reduced, rather than increased, system-wide risks-although such considerations were of no more concern for the typical voter than the manner in which steel is produced and fabricated for automobiles. ${ }^{23}$ In 2004, home ownership rates peaked at $69.2 \%$. As long as "it works," why should voters worry about the details?

\subsection{Warnings about mortgage-backed securities and responses to them}

There were, however, growing concerns expressed by experts inside and outside government, who feared that the now-global system of mortgage finance had become overextended, in part because housing prices were rising at unsustainable rates, and in part because it appeared that the risks associated with mortgage-backed securities and their derivatives were underpriced. ${ }^{24} \mathrm{~A}$ variety of congressional hearings were held regarding sub-prime mortgages, and regulations designed to limit their terms were adopted by Congress, although many believed that such regulations had not gone far enough (Gramlich 2000). Concerns were also expressed about the viability and oversight of Fannie Mae and Freddie Mac, who were major purchasers of mortgages, as well as major sources of mortgage insurance and mortgage-backed securities. Several proposals were advanced to strengthen and depoliticize their standing regulator (OFHEO) and to increase their capital requirements, but none were able to secure majorities in Congress, in part because of successful lobbying efforts by Fannie Mae and Freddie Mac and in part because promoting home ownership was a popular cause.

\footnotetext{
${ }^{23}$ For example, in a May 8, 2003 speech then-Chairman of the Federal Reserve Alan Greenspan argued that derivatives had insulated the financial system from the stock market crash of 2000 (the dot.com bubble) and the associated economic downturn. He did, however, express reservations about the concentration of the derivative market in the hands of a few investment bankers.

${ }^{24}$ The underpricing of risks evidently was compounded by incentives facing the various asset rating services of Standard and Poor's and Moody's. Much of their revenue comes from rating services and security issuers could shop among the top firms for the best ratings. AAA ratings consequently were achieved for many asset bundles that were only of low risk as long as housing prices continued to rise or at least did not decline very much (Jenkinson 2008).
} 
Such pressure, however, induced Fannie Mae and Freddie Mac to register (voluntarily) with the SEC in 2003, which required them to file the same quarterly and annual financial reports as other stockholder-owned firms. (Fannie Mae and Freddie Mac were exempt from the 1933 Securities Act as GSEs.) This required Fannie and Freddie to meet conventional accounting standards in their financial reporting, which they had not done previously. At about this time and for much the same reason, the OFHEO conducted a thorough investigation of Fannie Mae and filed a 200-page report, in which it stated, for example, that:

We have determined that Fannie Mae, in developing policies and practices in these critical areas, has misapplied Generally Accepted Accounting Procedures (GAAP), specifically Accounting for Nonrefundable Fees and Costs Associated with Originating or Acquiring Loans and Initial Direct Costs of Leases ("SFAS 91") and Accounting for Derivative Instruments and Hedging Activities ("SFAS 133").

... The misapplications of GAAP are not limited occurrences, but are pervasive and are reinforced by management. The matters detailed in this report are serious and raise concerns regarding the validity of previously reported financial results, the adequacy of regulatory capital, the quality of management supervision, and the overall safety and soundness of the Enterprise. (Emphasis is in the original report, Dickerson 2004: 6.)

Of course, similar accounting irregularities that overstated profits may have occurred at other large financial enterprises, which can shop around for pro-management accounting and rating firms. Those filings, however, had long been reviewed by the SEC and were subject to the GAAP standards. Private firms also faced somewhat higher and more binding rules for capital requirements. ${ }^{25}$ Fannie Mae and Freddie Mac are, in principle, monitored by both stockholders and voters (through their agents) as well as HUD. Monitoring failures are, however, evident throughout the OFHEO report. ${ }^{26}$

On February 24, 2004, Federal Reserve Chairman Alan Greenspan urged Congress to address the financial basis and possible bankruptcy of Fannie Mae and Freddie Mac.

The Federal Reserve is concerned about the growth and the scale of the GSEs' mortgage portfolios, which concentrate interest rate and prepayment risks at these two institutions. Unlike many well-capitalized savings and loans and commercial banks, Fannie and Freddie have chosen not to manage that risk by holding greater capital.

In sum, the Congress needs to create a GSE regulator with authority on a par with that of banking regulators, with a free hand to set appropriate capital standards, and with a clear process sanctioned by the Congress for placing a GSE in receivership.

However, if the Congress takes only these actions, it runs the risk of solidifying investors' perceptions that the GSEs are instruments of the government and that their debt is equivalent to government debt. The GSEs will have increased incentives to

\footnotetext{
${ }^{25}$ Fannie Mae's (2007) Annual Report (pg. 1) states that Fannie held 27 billion of core capital in 2003 to support 2.2 trillion dollars of obligations on its Mortgage Credit Book of Business. Similar ratios were evident in the years after its capital requirements were increased by OFHEO in 2005. For example, in 2006, Fannie had 42 billion dollars of core capital on hand to support 2.5 trillion dollars of credit.

${ }^{26}$ Several very well-paid top officials of Fannie Mae, including its CEO, were "encouraged" to resign as a consequence of the OFHEO report and other investigations undertaken by the SEC. The SEC and OFHEO subsequently fined Fannie Mae \$400 million in 2006 for manipulating its accounts, from 1998 to 2002, to enrich its senior management (Day 2006).
} 
continue to grow faster than the overall home mortgage market. Because they already purchase most conforming mortgages, they, like all effective profit-maximizing organizations, will be seeking new avenues to expand the scope of their operations, assisted by a subsidy that their existing or potential competitors do not enjoy. Thus, GSEs need to be limited in the issuance of GSE debt and in the purchase of assets, both mortgages and nonmortgages, that they hold. ${ }^{27}$

Indeed, by 2006, even Fannie Mae's annual report mentions heightened risks in the housing finance market. For example, regarding its own portfolio of sub-prime mortgages, the 2006 report notes on page 23 that:

The proportion of higher risk mortgage loans that were originated in the market between 2003 and mid-2006 increased significantly. As a result, our purchase and securitization of loans that pose a higher credit risk, such as negative-amortizing adjustable-rate mortgages ... interest-only loans, and sub-prime mortgage loans, also increased, although to a lesser degree than many other institutions. In addition, we increased the proportion of reduced documentation loans that we purchased to hold or to back our Fannie Mae MBS. (Emphasis added.)

That housing prices were at relatively high levels and that market portfolios included many risky mortgages was not a surprise. There were warnings about a bubble in home prices from a broad cross-section of newspapers and economists, as with Case and Shiller $(1989,2003)$ and Yellen (2005), although there was not complete agreement (Himmelberg et al. 2004) ${ }^{28}$ Congressional hearings had been held, and financial columns in newspapers and news magazines had both analyzed the risks associated with the portfolios assembled and supported by Fannie Mae and Freddie Mac and raised concerns about mortgage-backed securities generally throughout the previous decade.

It bears noting, however, that there was a tradeoff between Fannie's and Freddie's legal responsibility to support orderly mortgage markets and to foster home ownership among those who lacked the means to obtain ordinary (prime) mortgages. HUD, with the backing of Congress and two presidents, pressed for the latter, because it appeared to be a costeffective (and was an off-budget) method of subsidizing housing. The HUD requirements imposed to purchase more and more loans from low- and middle-income groups, together with competition from other unregulated mortgage purchasers, induced the GSEs to buy or guarantee mortgages from less and less creditworthy persons (and mortgage originators) with term structures that were less and less likely to be viable.

There was, however, far less analysis of the global markets for mortgage-backed securities in general, which widely were presumed to be efficient in the sense of stock markets, although those relatively new markets lacked equivalent regulation and transparency. ${ }^{29}$ The

\footnotetext{
${ }^{27}$ The texts of Greenspan's testimony and other written statements submitted by Federal Reserve officials are available at www.federalreserve.gov.

${ }^{28}$ It is interesting to note that Himmelberg worked for Goldman Sachs, a leading investment bank, at the time when the Himmelberg et al. (2004) report on housing prices was written for the Federal Reserve Board. Early analyses of housing bubbles are provided by Case and Shiller (1989), Abraham and Hendershott (1994), and Malpezzi (1999).

${ }^{29}$ See, for example, the speech by C.S. Spatt, chief economist at the SEC, given at the "Derivatives-Based Investments" conference on December 8, 2005. That speech mentions a variety of factors that led to the growth of derivative trading, but does not list bubbles or "irrational exuberance" among the possibilities. It does however discuss informational problems that can exist in some circumstances and the difficulties of properly pricing assets that are triggered by somewhat unlikely events (www.sec.gov/news/speech/spch120805css.htm). Mason and Rosner (2007) discuss risks associated with mortgage-backed securities, but not system-wide risk.
} 


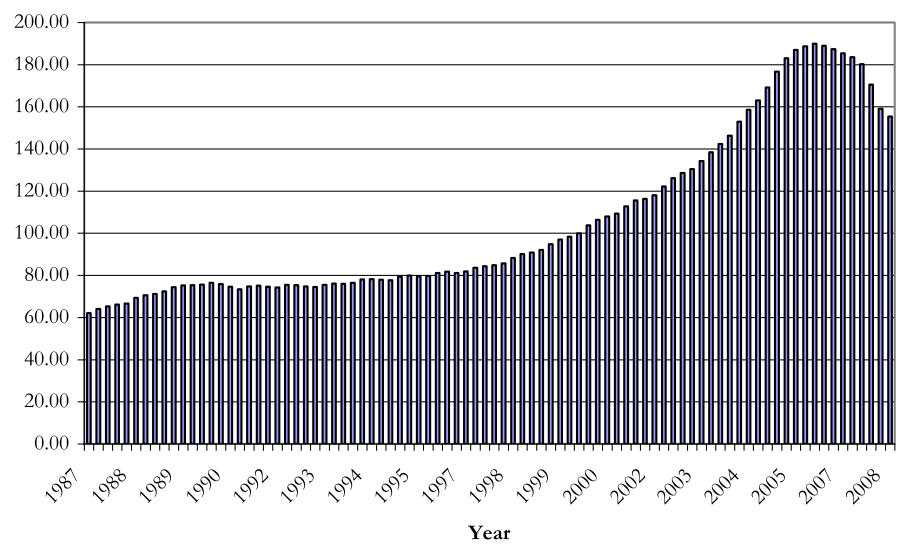

Fig. 3 Case-Shiller U.S. home price index

problems in the mortgage-backed securities market that emerged in 2007-2008 thus were more of a surprise than the ending of the housing bubble and rising delinquencies in subprime mortgages. Prior to the meltdown, only a small minority of economists recognized the system-wide financial risk associated with the highly leveraged portfolios of mortgagebacked securities and similar assets created by the finance industry. After all, the ModiglianiMiller (1961) theorem implied that the market value of a firm is independent of its method of financing, i.e., independent of its debt-equity mix. The empirical limits of that theorem were soon to be tested.

\subsection{The end of the housing bubble}

As long as housing prices continued to rise, the asset values of the houses supporting the sub-prime mortgages were sufficient (indeed more than sufficient) to support such relatively risky loans, which together with easy refinancing allowed relatively high profits for mortgage bundler/insurers like Fannie Mae and Freddie Mac and also for loan originators and homeowner speculators. The bubble warnings finally proved to be correct in 2006-2007, and housing prices began to fall for the first time in more than a decade. The subsequent steep decline was the first significant U.S.-wide housing price downturn since the recession in 1992, and the downturn was much greater and faster than in that relatively mild recession. According to the Case-Shiller index (see Fig. 3), average U.S. home prices peaked in 2006 and fell by about $18 \%$ in the next two years. The U.S. Census series on median home prices peaked in 2007 and shows a similar broad decline in home prices during 2007-2008. Diversifying across regions of the country could not lower this risk, as average house values fell throughout the United States. (Indeed a few real estate bubbles also burst in other countries at about the same time.)

Although explanations for the existence and piercing of asset bubbles vary (Capozza and Seguin 1994; Lei et al. 2001; Gjerstad and Smith 2009), there is little disagreement among economists that the end of a major asset bubble can have real effects on other markets. For example, Case et al. (2001) find that both stock market and real estate price fluctuations have significant effects on household consumption levels, and they report that the effects of housing price declines are larger than those from stocks. Cecchetti (2008) reports that housing booms worsen growth prospects, although equity booms have little impact on macroeconomic performance. The $18 \%$ decline in U.S. home values between 2006 and 2008 reduced homeowner equity by more than $\$ 3.4$ trillion. 


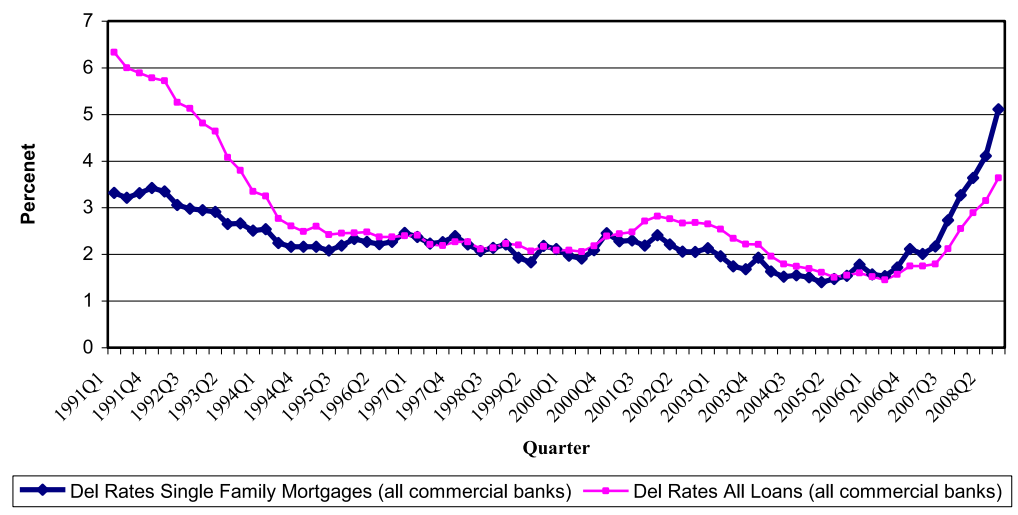

Fig. 4 Delinquency rates at all commercial banks residential mortgages and all loans 1991-2008 (quarterly, seasonally adjusted, FRB)

\subsection{The end of "risk-free" mortgage-backed securities}

Delinquencies on residential mortgages were moderate in the period after the 1992 recession and, if anything, exhibited a slight downward trend through 2005 (see Fig. 4). Delinquencies on residential real estate loans, however, more than doubled by the beginning of 2008 and continued to climb. Nearly $25 \%$ of sub-prime mortgages were 90 days delinquent or in foreclosure at the end of 2008 (Bernanke 2009). ${ }^{30}$ Delinquency rates on residential real estate were exacerbated by the almost fraudulent lending practices of many loan originators, real estate price assessors, and some builders. ${ }^{31}$ Most purchasers of "negative equity" and "no docs" mortgages realized that these were relatively risky "promises" to pay for. For example, Fannie Mae acknowledged such risks, as noted above. The purchasers of mortgage-backed securities based on them nevertheless had been assured that those risks had been diversified and properly insured, as attested to by the risk assessments of Fitch, Moody's, and Standard and Poor's.

The reduction in house values and reduced economic growth after 2006-2007 made subprime and prime mortgages riskier than in previous years, because the asset values of the houses supporting the mortgages were in many cases less than the values of the outstanding mortgages. Refinancing to ease borrower cash-flow problems no longer was possible. The end of the housing bubble also had direct and predictable wealth effects on private consumption for those without cash-flow problems, which increased unemployment throughout much of the United States. Delinquencies predictably began to rise, and sub-prime mortgages were represented disproportionately among the delinquencies.

\footnotetext{
${ }^{30}$ Bernanke (2008: figures 1 and 2 ) shows that delinquency rates varied widely across the country from $0.6 \%$ in the lowest quintile to more than $2.5 \%$ in the highest quintile in 2004 , which was a relatively good year. During 2004-2007, delinquencies rose in many parts of the Southwest, Southeast, and Midwest, while relatively few delinquencies occurred in most parts of the Northwest.

${ }^{31}$ Monthly payments on "negative equity loans" are initially below those required by the interest on the loan; the implicit loan made during the "negative equity period" is subsequently capitalized into the principal, after which much higher monthly payments are required. "No docs" loans are mortgages for which no proof of income (or ability to repay) is required by the borrower. Many variable-rate mortgages have initial periods in which the interest due is well below the rates that will be paid after a year or two. (It is interesting to note that many academic papers on the pricing of mortgage-backed securities focus entirely on the "prepayment" risk and neglect the risk of default. See, for example, Stanton (1995).)
} 
Although residential mortgage delinquency rates began to climb in 2005 (see Fig. 4), most mortgages and mortgage-backed securities initially remained relatively "low-risk" assets, because most were guaranteed by Fannie Mae, Freddie Mac, and other mortgage and mortgage-backed security insurers. About half of all mortgages and, therefore, mortgagebacked securities were insured by Fannie Mae and Freddie Mac. Residential mortgages had long been safer than most other loans, but this optimistic presumption was replaced with pessimistic ones that appear to exaggerate their risks. ${ }^{32}$ However, the rapid decline in prices for mortgage-backed securities was only partly caused by changes in the risks associated with the mortgages themselves.

In addition to reassessing the risk of mortgage defaults, the value-added by various insurance instruments was also gradually reassessed. As delinquency rates began to exceed the normal range of the post-1992 period in 2007, insurance claims began to increase, and mortgage and mortgage-backed securities insurers had to pay the insurance claims (make the interest payments that delinquent borrowers were not making). ${ }^{33}$ Unfortunately, but perhaps predictably, insufficient reserves had been maintained by the insurers of mortgages and mortgage-backed securities, because they had evidently assumed that the benevolent national trends between 1995 and 2005 were the new market norm. As the risk of default by insurers rose, the risks associated with asset-backed securities increased and their values fell rapidly as potential buyers predictably demanded ever larger risk premiums.

Insurance is only as good as the insurance company's net cash flow, portfolio of reserves, and line of credit. As housing prices began to fall even more rapidly than they had been rising and economic growth diminished, delinquencies and foreclosures increased (especially among sub-prime mortgages) and the mortgage insurers began to pay out more than they were collecting in fees and interest. Unfortunately, reserves that had been more than adequate during the housing boom turned out not to be sufficient during the ensuing and unusually rapid decline. As housing prices fell rapidly in many parts of the country, reselling houses took longer (requiring insurers to make up more missing interest payments), and because the houses sold were less valuable than they had been in the recent past, interest payments from the new loans taken out by successive home owners were reduced. The insurers of mortgage-backed securities began to empty their reserves and their lines of credit dried up.

This was not simply a cash-flow problem that could be solved with a bit of temporary borrowing. There was $\$ 10.4$ trillion worth of outstanding mortgages on one- to fourfamily homes in 2006, of which $\$ 7$ trillion was held in mortgage pools and trusts supporting mortgage-backed securities (Statistical Supplement to the Federal Reserve Bulletin, October 2008: 33). The value of the mortgage-backed securities supported by those mortgage pools would initially have exceeded the value of the mortgage pools themselves, because of the lower risk premiums paid for securitized mortgages than for the mortgages themselves, as noted above.

\footnotetext{
${ }^{32}$ As default rates increased, Standard and Poor's reassessed the value of some mortgage-backed securities. For example, under the default rates of early 2009, they estimated that the fair value of one sub-primesupported MBS had declined $13 \%$ from its original value. Under the assumption that default rates would double, the value of the MBS would have declined by $47 \%$. The market, however, priced the MBS at $62 \%$ less than its initial value, well below Standard and Poor's worst-case analysis (Bajaj and Labaton 2009).

${ }^{33}$ The St. Louis Federal Reserve Bank's "Financial Crisis Timeline" notes that in June 2007 Standard and Poor's and Moody's Investor Services downgraded more than 100 bonds backed by second lien sub-prime mortgages. A month later, more than 600 securities backed by sub-prime residential mortgages were placed on a credit watch (www.stlouisfed.org/timeline/timeline.cfm). See also Jenkinson (2008), who analyzes the downward revisions of "structured" securities by rating agencies in 2007 by more than one rating category.
} 
As insurer losses accumulated, the market prices of their equities naturally fell, which meant that they could not raise new money to make their "guaranteed payments" to mortgage-backed security holders by selling stock. At the same time, Freddie Mac, Fannie Mae, and other insurers saw their credit ratings decline rapidly as the credit-rating agencies revised their estimates of expected insurance losses. Insurers could no longer borrow to pay claims in the short run. Losses accumulated as payments to those who had been insured exceeded payments from those holding the mortgages.

The standard asset-pricing models could no longer be used to assess the values of mortgage-backed securities, because house prices continued to fall at unusually high rates and bankruptcy risks rose to unusual levels for even the most robust mortgage insurance companies. (The standard asset-pricing models assume that the distributions of risk are known, or at least can be accurately estimated.) Several large financial corporations filed for bankruptcy protection in 2007. Many of these were insurers of mortgage-backed securities. New Century Financial Corporation filed for bankruptcy in April, Countrywide Financial Corporation in July, and American Home Mortgage Investment Corporation in August. Several other major insurers approached bankruptcy, as their insurance obligations exceeded their reserves (Fannie Mae, Freddie Mac, AIG).

Ex post, it is clear that the insurers of mortgage-backed securities had assumed (or hoped) that housing prices would rise forever (or at least not fall very much), which essentially meant that they needed reserves sufficient only to carry properties through bankruptcy courts, after which houses would be resold and interest payments would be resumed (from new buyers, whose mortgages were also likely to be purchased).

All this implies that there was a bubble in mortgage-backed securities built on top of the bubble in housing prices, as investors around the world were encouraged to hold these relatively "safe" assets, rather than government securities. ${ }^{34}$ The bubble in MBSs was amplified by of a variety of mistakes made by credit rating agencies that under-assessed the risks associated with mortgage-backed securities and their derivatives (Jenkinson 2008). There were far too many trust-based transactions.

Some newspaper accounts place the lost market value of mortgage-backed securities at between $60 \%$ and $80 \%$, depending on the type of security, which, if true, implies that on the order of $\$ 5$ trillion of financial wealth disappeared from the world's financial system from that one market alone. These losses were about of the same magnitude as the reduction in homeowner equity, but they had larger real effects because they were concentrated in one very important and well-organized sector of the economy, rather than being spread out among independent households. That concentration increased both its economic and political consequences, in part for Olson (1965) reasons.

\subsection{Pecuniary externalities from the decline in real estate prices}

The decline in residential real estate values and the (effective) end of mortgage and mortgage-backed security insurance had three broad effects on the U.S. and world economies. (1) The lower values of real estate and mortgage-backed securities reduced the wealth of homeowners and all organizations holding mortgage-backed securities. These wealth effects caused consumers to cut back on their expenditures and firms to cut back

\footnotetext{
${ }^{34}$ Several Asian governments, for example, were encouraged to invest in mortgage-backed securities as an alternative to U.S. Government securities. Foreign holdings of mortgage-backed securities issued by U.S. GSEs rose from $\$ 124.9$ billion in 2002 to $\$ 385$ billion in 2006. (U.S. Treasury International Capital System Report on Foreign Portfolio Holdings of U.S. Securities, tabulated by HUD, May, 2007).
} 
on their investments. (2) Mortgage-backed securities were deemed riskier and less valuable assets. Consequently, those managing portfolios at investment banks, insurance companies, pension funds, and sovereign wealth funds all attempted to reduce their portfolios' overall risks. In the new circumstances, most owners of mortgage-backed securities found themselves with far too many risky assets in their portfolios and tried to sell those securities in the usual way. Mark-to-market accounting rules amplified the need to rebalance portfolios, because as capital evaporated firms had to increase their assets and reduce their debts immediately, or face bankruptcy. (3) The decline in non-bank sources of credit reduced the ability of other highly leveraged firms to refinance their debts, take out short term loans to cope with temporary cash flow problems, or purchase new capital equipment. (4) Many financial firms effectively were bankrupt, with debts and collateral obligations that were greater than assets, because their capital bases had evaporated as risks were reassessed.

The rebalancing generated additional declines in wealth for those holding relatively risky assets in their portfolios, as many money managers worldwide sold what they could (stocks and less than perfectly safe corporate bonds) and replaced them with safer government securities. Stock market values fell to decade lows worldwide, while interest rates on government securities also fell as a result of demand-side pressures on prices. The portfolio effect thus reinforced the wealth effect, because essentially everyone was trying to make the same adjustments at essentially the same time. There were many more sellers than buyers at the old prices, and prices for relatively risky securities fell while those of nearly risk-free assets increased, as predicted by the elementary economics of supply and demand. The U.S. residential real estate, mortgage-backed securities, and stock markets are huge markets, so these unusually large adjustments had unusually large consequences for U.S. and world markets.

The more than $\$ 10$ trillion reduction in wealth lowered consumption and investment expenditures, which also reduced the demand for all inputs. The securitized debt market collapsed. Unemployment increased and oil prices fell. There were bankruptcies of unusually large financial firms. Economic growth fell throughout the world.

It bears noting that the financial firms that failed in 2007-2008 were remarkably large, in part, because of changes in U.S. bank regulations during the past two decades. These changes allowed inter- and intra-state mergers and consolidation to take place on a major scale and also facilitated the internationalization of finance. During the previous U.S. housing crisis of the late 1980s and early 1990s, there were many more bankruptcies, but those were of smaller firms.

About 750 savings and loan banks failed during the late 1980s, with $\$ 400$ billion of "book" assets. The assets of the failed S\&Ls were purchased by U.S. Government agencies (chiefly by the Resolution Trust Corporation, created specifically for that purpose). As those assets were resold, the market values of the loans of the bankrupt S\&Ls turned out to be about $25 \%$ less than their book values. In the end, taxpayers paid about $\$ 90$ billion more for those questionable mortgages than they recovered by selling them. ${ }^{35}$ The $\$ 400$ billion program to restore the S\&L industry had until 2008 been the largest "bailout" in U.S. history.

\section{Political responses to the threat of recession and the "financial meltdown"}

There are a variety of standing government procedures for limiting the downside risks of mortgage defaults and recessions in the United States. Some of these, such as unemployment

\footnotetext{
${ }^{35}$ See the General Accounting Office's (GAO’s) audit (1996) of the Resolution Trust Corporation.
} 
and mortgage insurance, are automatic and require no new policy decisions by government officials. Others require a variety of more or less routine actions within standing government agencies. The FDIC and Federal Reserve have responsibility for looking after the solvency of banks, managing the money supply, and monitoring the soundness bank credit. Other policy initiatives require the adoption of new legislation. Keynesian responses to recessions beyond those provided by existing social insurance programs demand congressional action with respect to budget and/or tax law. Modifying bankruptcy rules to address an unusually large wave of bankruptcies outside the banking sector would require new legislative authority. There is no equivalent to the FDIC for non-bank financial institutions, beyond the usual civil laws that govern routine bankruptcies.

Relatively little political pressure is needed to prompt the standing institutions to respond to changes in banking markets or recessionary pressures; so, for example, the FDIC arranged for mergers of failing banks with more robust banks, and the Federal Reserve Bank stepped in to provide liquidity, at first with more or less routine adjustments to the Federal funds rate. These were quietly followed by a variety of policy innovations in late 2008 and early 2009 to reach financial firms that normally were beyond the Fed's regulatory turf. ${ }^{36}$ Target Federal funds rates were reduced gradually from $5.25 \%$ in early 2007 to $0.25 \%$ in late 2008 . The range of assets purchased in monetary-base-expanding open market operations and used to secure short-term loans from the Federal Reserve was broadened to include relatively safe corporate bonds and mortgage-backed securities.

\subsection{Great Depression warnings are sounded}

Responses from the Department of the Treasury, however, required new legislation, which provoked significant lobbying of Congress both by top Executive Branch officials and large financial firms. The terms "financial crisis" and "credit meltdown" were often used by those advocating new governmental funds and authority to address the unusually large number of bankruptcies (and potential bankruptcies) in the non-bank portion of the financial sector. At the time these terms were first invoked, there was no publicly available evidence of a broad credit "meltdown" nor of unusual recessionary pressures. ${ }^{37}$ Commercial bank credit expanded throughout 2007 and most of 2008, and corporate bond rates remained relatively low (see Figs. 5 and 6). Unemployment rose somewhat, but remained at historically low levels. Many financial firms, however, were in dire straits, because their asset bases had collapsed.

In response to that lobbying, as well as to macroeconomic concerns, legislation was adopted to reduce recessionary pressures, beginning with a Keynesian stimulus program of tax rebates adopted on February 13, 2008. The government's implicit guarantees for Fannie Mae and Freddie Mac were made more explicit, with new lines of credit from the Treasury

\footnotetext{
${ }^{36}$ The St. Louis Fed's “The Financial Crisis, A Timeline of Events and Policy Actions" includes a long list of policies adopted by the Federal Reserve in response to recessionary pressures and problems in the non-bank portion of the financial market.

${ }^{37}$ Research at the Minnesota Federal Reserve demonstrates that credit of all kinds continued to expand through mid-October 2008. Indeed credit demand (and supply) outside the financial sector increased during 2008 and very rapidly, both because of the recession (and associated cash-flow problems) and because of fears that credit might eventually dry up given all of the talk in the mass media about a credit crisis (Chari et al. 2008). The Federal Reserve system has provided a good deal of short-term credit to the banking system, which allowed banks to continue servicing credit cards, car loans, small business loans, and so forth, even if they held mortgage-backed securities on their balance sheets. The monetary base grew rapidly during this period. The securitized market for credit, however, declined rapidly.
} 


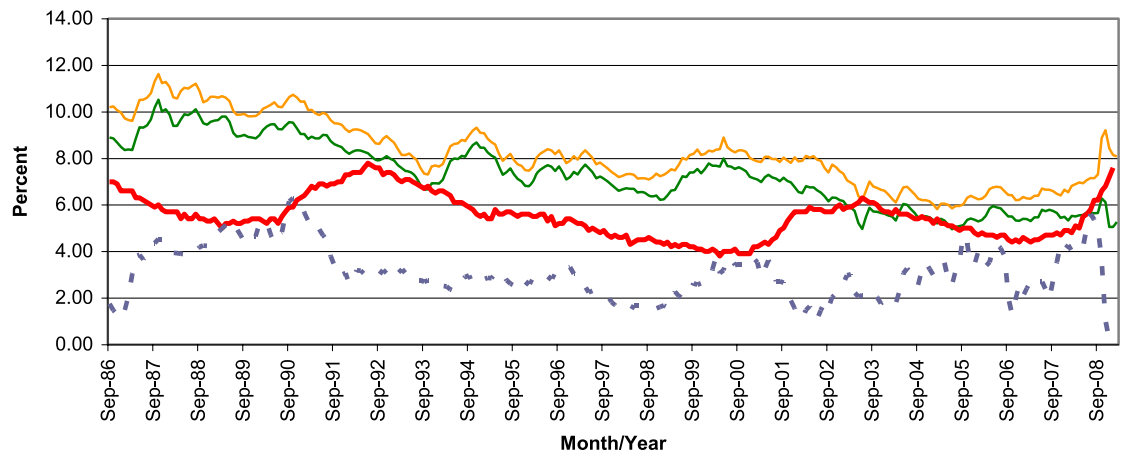

\begin{tabular}{|c|c|}
\hline AAA bond rates & BAA bond rates \\
\hline Unemployment rate & - = - Inflation rate (CPI year-to-year, all goods) \\
\hline
\end{tabular}

Fig. 5 Nominal interest rates, unemployment, and inflation 1986-2009 (monthly)

Total and Year-to-YearChange (pet)

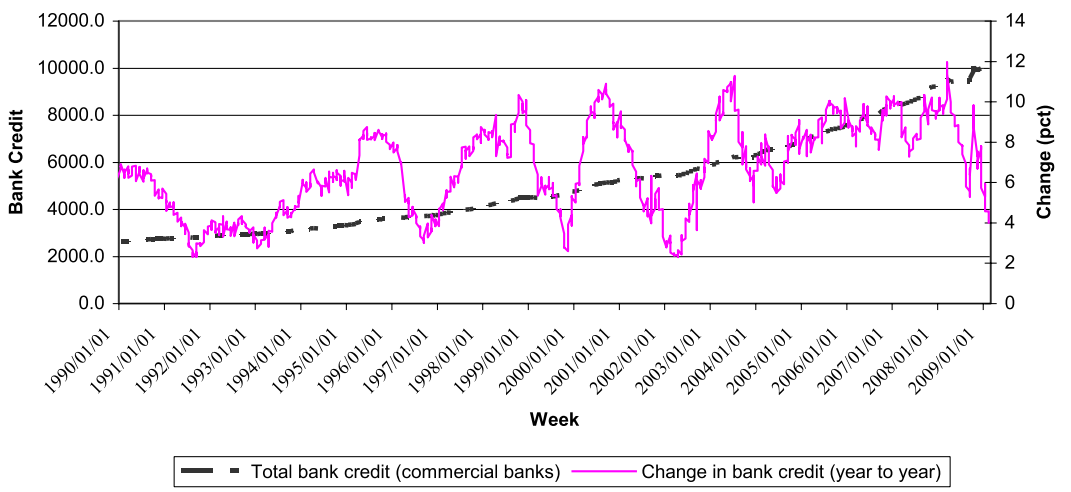

Fig. 6 Total commercial bank credit (1990-2009 weekly)

and the Federal Reserve provided in late July. The Housing and Economic Recovery Act of 2008 authorized the Treasury to purchase GSE obligations and merged the various GSE regulators within HUD to form a new Federal Housing Finance Agency. On September 7, 2008 both Fannie Mae and Freddie Mac were placed under conservatorship, effectively (re)nationalizing these privately held GSEs.

By doing so, the foundations of a large part of the financial market dealing with mortgage-backed securities was now formally guaranteed by U.S. taxpayers, because Fannie Mae and Freddie Mac guaranteed a significant fraction of the market for mortgage-backed securities, either directly or indirectly. However, the mortgage-backed securities issued by other firms were not yet supported. On September 16, an $\$ 85$ billion loan was provided to American International Group (AIG), one of the largest remaining private insurers of mortgage-backed securities and other similar securitized-debt securities.

Later in September, Treasury Secretary Paulson made a strong case (with predictions of a looming Great Depression) to persuade Congress to provide $\$ 700$ billion to purchase other mortgage-backed securities (the so-called "troubled" or "toxic" assets). Because these assets were held widely and had lost much of their value, many banks and other financial institu- 
tions actually were bankrupt, rather than merely illiquid (the latter problem was addressed by Federal Reserve policies).

Paulson proposed "restarting" the market for mortgage-backed securities and similar assets by adding a new major purchaser for those securities, namely the federal government. Given the size of his proposal and the urgency of the case presented, it was not surprising that it attracted enormous press attention, while the major steps already taken by the Federal Reserve and FDIC faded into the background. As usual, the most persuasive public arguments for private transfers are based on public goods arguments and emergency needs, and as usual a "crisis" can induce rapid policy changes without significant deliberation or analysis (Congleton 2005; Higgs 1987). ${ }^{38}$

\section{Public choice lessons from the fiscal crisis}

The process of passing the bailout bill in late September and early October of 2008 and the kinds of arguments used to secure its passage both shed a good deal of light on the incentives that individual members of Congress routinely operate under. Public support for the bailout was never strong, but public opinion can shift rapidly, and a national election was to take place in November. An enormous "all-or-nothing" offer of the Niskanen (1971) variety was presented to Congress, in which there was a strong presumption that the Secretary of the Treasury and the Chairman of the Federal Reserve knew more than the general public, Congress, or outside experts (as in Breton and Wintrobe 1975). The "experts" presumably had access to data that no one else had and used that information to sound alarms that the world economy was about to collapse. (Such rhetoric was deployed in spite of the fact that such a collapse had not happened since the first years of the Great Depression, and that standing institutions subsequently had been given responsibilities for preventing such a collapse.) A good deal of the initial talk of "crisis" was evidently prompted by the financial sector itself, because many of its firms (and employees) stood to profit if a major intervention by the Federal government could be induced. Additional crisis talk was induced by the natural proclivity of the news media to use that term to expand their audience. ${ }^{39}$

The available data suggest that worries about a "credit crisis" and "meltdown" were exaggerated during most of 2008. Two of the three major market credit markets (commercial banks and corporate bond markets) showed little effect, although the credit market based on securitized debt was experiencing great distress, because of the simultaneous declines in housing, common stock, and the values of mortgage-backed securities. The International Monetary Fund's World Economic Outlook of April 2008 noted that the financial shock was the worst since the Great Depression, a significantly milder claim.

\footnotetext{
${ }^{38}$ There is some evidence that the "Great Depression" rhetoric used to secure passage of the bailout bill exacerbated the credit problem and the recession. Because individual investors and firms naturally assume that Treasury experts have the very best data, the risk of another Great Depression apparently was "new news" to many of them. Note that AAA-BAA corporate bond spreads widened after September's testimony, while RGDP growth plummeted and unemployment increased rapidly —in the absence of other obvious new shocks. (Here, one might contrast Paulson's testimony before Congress with the understatement and care with which Greenspan normally spoke in public.)

${ }^{39}$ The terms "financial" and "crisis" have appeared in nearly 6,000 articles in The New York Times alone since 2004 and more than 30,000 times since 1851 . Nonetheless, the term financial crisis rarely was applied to the U.S. financial system in 2007, except occasionally by persons speculating that a crisis might occur at some point in the future.
} 
The forceful "Great Depression" arguments used in Congress naturally persuaded many investors that things were worse than they had thought (the risks were higher), and so, stock markets continued to decline, even as capital and liquidity liberally were added to financial markets. Whether the capital injections and loan programs were addressing public goods problems or providing transfers to senior managers of financial companies (and perhaps shareholders) depends on one's political and macroeconomic perspective. That significant government transfers to financial institutions took place as a result of TARP funds has been affirmed in congressional testimony. ${ }^{40}$

\subsection{An all-or-nothing offer}

The original Paulson proposal of September 20 was a "back of the envelope" idea, only three pages long, which requested a $\$ 700$ billion line of credit for Treasury to use as it saw fit to purchase "troubled securities." No other number was discussed seriously, as Paulson used his authority to focus attention on a single, large Troubled Asset Relief Program (TARP) that would purchase mortgage-backed (and similar) securities, whose complexity, it was argued, had made them very difficult to price in the new riskier environment and had induced an unreasonable sell-off (panic). The spending authority proposed represented about $10 \%$ of the value of the (pre-collapse) market for mortgage-backed securities and about $20 \%$ of the value not already supported by the nationalization of Fannie Mae and Freddie Mac. The amount thus was large enough to make a difference in a very large financial submarket.

The proposal, however, required a $25 \%$ increase in the federal budget and a significant increase in national debt ceilings. The national debt in 2008 was approximately $\$ 10$ trillion, so the Paulson plan required about a 7\% increase in the total debt of the United States. This would require an extraordinary issue of new Treasury bonds. The deficit in the previous year (2007) was about $\$ 240$ billion (down from $>\$ 400$ billion a few years earlier). Naturally, Congress initially was skeptical of the proposal, although after 10 days of testimony and a decline in the stock market, members of both the House and the Senate deferred to Treasury's expertise on the matter.

In the first round of negotiations, the House of Representatives added a variety of oversight provisions, created a new mortgage insurance program (insisted on by a number of House Republicans), and provided for a temporary increase in the accounts eligible for FDIC deposit insurance (from $\$ 100,000$ to $\$ 250,000$ ). The bill also reduced by half the resources initially available to the Treasury and included provisions for resources to be used to "keep persons in their houses," where possible, and for the purchase of preferred shares, an option discussed only in passing in congressional hearings. It also granted the SEC permission to suspend the market-to-market accounting rules that apply to financial institutions. The new, 110-page document, however, failed to secure a majority in the House on September 29 (losing by a vote of 205 to 228 ).

The stock market fell $6.98 \%$ on the day a majority in the House rejected the revised Paulson plan. The news media attributed the loss to the House vote, although the stock market rebounded $4.7 \%$ the following day. ${ }^{41}$ The Senate took up the (unpassed) House version of

\footnotetext{
${ }^{40}$ Elizabeth Warren, chairwoman of the TARP oversight panel, testified on February 5, 2009, that $\$ 250$ billion was paid for $\$ 176$ billion worth of assets, the latter being the estimated risk-adjusted value of the preferred shares the government purchased. Some preferred shares were far riskier than others, but the same price was paid for every firm's shares.

${ }^{41}$ See the October 1 press release on "The Bad Rap on the Bailout Bill." Perhaps, surprisingly, members of Congress facing close elections in November voted against the bill the first time it was voted on in the House.
} 


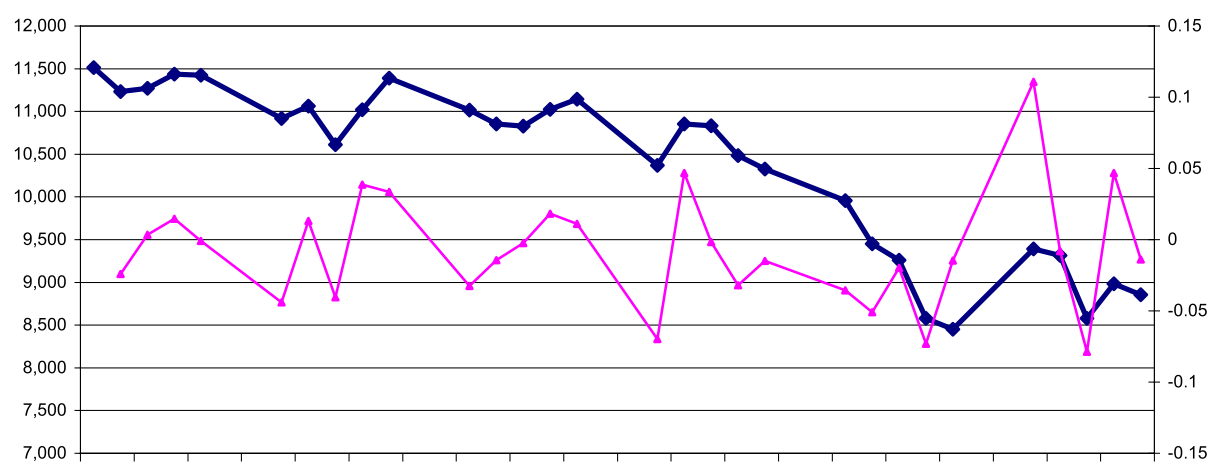

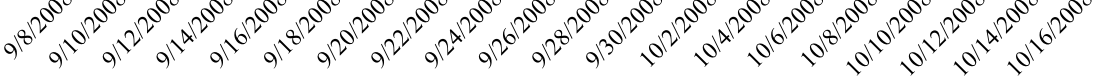

Trade Day

Dow Jones Industrial Average (close) $\longrightarrow$ Percent Change Dow Jones Average

Fig. 7 Dow Jones average and percent change in September-October of 2008

the TARP bill and added a variety of provisions, both major and minor, unrelated to its stated purpose. The new TARP bill raised the income threshold for the alternative minimum tax, extended environmental and other tax credits, and adopted other minor tax reforms. About two-thirds of the now 450-page-long bill had little to do with the financial crisis, but the "sweeteners" allowed the bill to secure overwhelming support in the Senate (75 to 25). The House, chastened by the stock market decline of September 29 and evidently attracted by the Senate sweeteners, passed the Senate version of the bill two days later (263 to 171), largely on the basis of Democratic support. President Bush signed it into law the same day, October 3, 2008. Polls in late September of 2008 showed a slight majority in favor of the bailout.

However, the stock market did not rebound as many television analysts had predicted, but rather continued to fall. ${ }^{42}$ Indeed, the largest percentage daily market decline in the period immediately before and after the TARP deliberations occurred on October $15(-7.87 \%)$, some 12 days after the augmented TARP plan was adopted (see Fig. 7).

\subsection{Crisis management and agency costs}

Given the congressional hearings and testimony by Treasury Secretary Paulson, one might have expected large-scale purchases of non-GSE issues of mortgage-backed securities to have begun immediately, with the Treasury paying well-above market prices. Instead, the U.S. Treasury announced on October 14 that the TARP funds would be used to purchase preferred shares in a subset of finance institutions, using authority added by Congress without much public discussion. The press release stated:

\footnotetext{
${ }^{42}$ The Dow Jones Industrial Average finished the day at 11,388 on the Friday before the plan was announced (September 19, 2008). The Paulson plan was proposed over the weekend. The Dow Jones average ended the day at 9,955 on the Monday after the bill was passed (October 6, 2008), a decline of $12.5 \%$ during the period of negotiations. The Dow continued falling in the days after the bailout was passed, reaching 8451 on October 10 , an overall decline of $25 \%$.
} 
Companies participating in the [capital purchase] program must adopt the Treasury Department's standards for executive compensation and corporate governance, for the period during which Treasury holds equity issued under this program.

Nine large financial institutions already have agreed to participate in this program, moving quickly and collectively to signal the importance of the program for the system. These healthy institutions have voluntarily agreed to participate on the same terms that will be available to small- and medium-sized banks and thrifts across the nation. (Department of Treasury Press Release October 14, 2008; emphasis added.)

On November 12, the Treasury announced that it would not use any of the TARP funds to buy troubled assets. These shifts in policy have never been explained. ${ }^{43}$

\subsubsection{Capture?}

Whether these major policy shifts simply reflected the usual informational problems of crisis management or is an instance of Stigler's (1971) capture theory of regulation is not clear.

The November 12 Treasury press release on the rescue package states that $\$ 115$ billion of TARP funds had been provided to the eight largest financial institutions by October $26 .{ }^{44}$ According to the October 14 press release, the preferred shares were to qualify as "Tier 1 capital" and pay dividends of 5\% a year for the first five years, followed by a dividend of 9\% a year until the shares are repurchased by the firms. ${ }^{45}$ Although the first announcement states that capital purchases were from "healthy institutions," few of the first recipients could be regarded as healthy. Among the nine large financial institutions listed on the November transaction reports were two investment banks, Morgan Stanley and Goldman Sachs, who received some $\$ 10$ billion of capital each (through purchase of preferred shares). The latter was the firm formerly headed by Treasury Secretary Paulson. Merrill-Lynch was eligible for $\$ 10$ billion, but was in the process of being acquired by Bank of America, because MerrillLynch's management evidently feared bankruptcy even more than merger. ${ }^{46}$ Citibank was authorized to receive an additional $\$ 20$ billion purchase of preferred stocks (on November 23) and obtained additional government guarantees for some of its troubled assets. On January 15, similar supplemental support was authorized for the Bank of America. ${ }^{47}$ Purchases of preferred shares from AIG ( $\$ 40$ billion) were authorized on November 10, although it is far from a healthy firm. Many of the investment banks and large commercial banks evidently had so many mortgage-backed securities on their capital accounts that they were

\footnotetext{
${ }^{43}$ The preferred share purchase program appears to be modeled after Gordon Brown's plan for bailing out banks in the United Kingdom.

${ }^{44}$ The press release states that "By October 26th we had $\$ 115$ billion out the door to eight large institutions."

${ }^{45}$ Tier 1 capital is defined by the Basel I and Basel II capital accords and is sometimes called core capital. It is interesting to note that U.S. bank regulations had to be adjusted to allow this particular type of preferred share to count as Tier 1 capital.

${ }^{46}$ The first recipients of government support under the TARP program were approved on October 28, 2008. They included the Bank of America ( $\$ 15$ billion), Bank of New York-Mellon ( $\$ 3$ billion), Citigroup ( $\$ 25$ billion), Goldman Sachs ( $\$ 10$ billion), J.P. Morgan Chase ( $\$ 25$ billion), Morgan Stanley (\$10 billion), State Street Corp. ( $\$ 2$ billion), Wells Fargo ( $\$ 25$ billion), and Merrill Lynch ( $\$ 10$ billion). The Merrill Lynch transaction was authorized on October 28 along with the others, but included a footnote stating that funds were delayed pending merger. See the Treasury's Capital Purchase Program Transaction Report, November 17, 2008.

${ }^{47}$ Joint Department of Treasury, Federal Reserve, FDIC Press Release on November 23, 2008. See also Irwin and Cho (2008) and the Department of Treasury press release January 16, 2009.
} 
formally bankrupt, and "shorting" the stocks of several of the bailout recipients was profitable throughout $2008 .^{48}$

TARP funds also were used to support nearly bankrupt auto companies through purchases of shares in their credit divisions. On December 29, the Treasury announced $\$ 5$ billion in preferred share purchases in General Motors Acceptance Corporation (GMAC)—which also invests in mortgages, and a loan of $\$ 1.5$ billion to Chrysler Financial on January 16, 2009. ${ }^{49}$ The automobile companies themselves were on the verge of bankruptcy with major cashflow problems. Perhaps surprisingly, the nonbank capital purchases were not listed on the Treasury's TARP transaction reports released in December and January. ${ }^{50}$

The extent to which such shifts in Treasury's policy and its lack of transparency were agile adaptations to rapidly changing circumstances or reflect agency costs and mistakes associated with the enormous discretion delegated to the Department of Treasury is not obvious. Many of Treasury's decisions appear to be consistent with regulatory capture theory, because they benefit the recipient firms and their employees far more than they do the taxpayers. Weak banks are unlikely to use their new capital for loans, because doing so would violate their reserve requirements. About $\$ 3.6$ billion in bonuses were paid to Merrill-Lynch employees at the end of 2008, although the company had losses of $\$ 27$ billion and was in line to receive $\$ 10$ billion from TARP funds. ${ }^{51}$

\subsection{On the cost-effectiveness of the bailout plan}

Both the cost and the cost-effectiveness of the purchase of preferred stocks in major financial firms depend on the viability of the specific companies in which shares are purchased, an outcome that will be determined largely by the length and depth of the current recession. If all of the firms survive and repurchase their preferred shares, the cost of the preferred stock portion of the bailout program to taxpayers will be relatively small. Congressional testimony on February 5, 2009, however, suggests that only about two-thirds of the subsidized banks (weighted by assets) are likely to survive. ${ }^{52}$

\footnotetext{
${ }^{48}$ Several of the first TARP recipients were unhappy about the purchase of preferred shares to the Treasury only after implicit threats were made by Secretary Paulson. (Interview of Sheila Bair, Chair FDIC, see http://www.pbs.org/wgbh/pages/frontline/meltdown/cron/.) A simple purchase of their "troubled" assets by the government would clearly have been more desirable for these firms and their shareholders, although it would have been far riskier for taxpayers.

${ }^{49}$ GMAC was a subsidiary of General Motors until 2006, when it sold 51\% of GMAC shares to a consortium including Cerberus Capital, Citigroup, and PNC. Cerberus is the investment group that purchased Chrysler and Chrysler Financial from Daimler (Mercedes Benz) in 2007.

${ }^{50}$ The initial terms of some "capital injections" have subsequently been modified, as with AIG, which received an $\$ 85$ billion loan from the Federal Reserve on September 16. On November 10, AIG received $\$ 40$ billion of TARP money through Treasury purchases of preferred shares, of which $\$ 25$ billion was used to "pay down" the loan. The interest rates on that loan were reduced at the same time. In effect, a third of the original September 16 loan had been quietly transformed into preferred shares, which reduced government claims in the event of an AIG bankruptcy (Department of Treasury press announcement on November 10, and the Federal Reserve press release November 10).

${ }^{51}$ News coverage of the Merrill Lynch bonuses has been extensive. See for example, Merced and Story (2009). Similar bonuses were paid at other failing investment banks as well. (Stronger restrictions on salaries and bonuses were included in the stimulus bill signed into law on February 17, 2009; which led many of the first recipients of public capital to try to buy back the government's preferred shares.)

${ }^{52}$ The difference between the price paid and the expected value received suggests that the probability of recovering principal, itself, is about 0.70 . Given the promised dividend payments, Elizabeth Warren's assessment implies that the probability the supported banks will survive is somewhat less than $70 \%$. See footnote 40 .
} 
The preferred share purchase plan improves the capital accounts of firms, but does not address the fundamental source of their balance sheet problems. Financial firms hold billions of dollars worth of formerly "safe" MBSs on their capital accounts. If these and similar assets were marked down to reflect their present market values, many institutions would be bankrupt, and many others would have capital below their required reserves and be required to reduce their debt (i.e., to "deleverage"). Providing such firms with public capital helps them to avoid bankruptcy only if their portfolios of mortgage-backed securities (and similar asset-backed derivatives) are temporarily underpriced by today's market, as they were temporarily overpriced by them before 2008 .

In that case, the cost of reorganizing the managements and investment portfolios of very large banking and financial institution will have been avoided by temporary additions of public capital. Such injections of capital also benefit other firms, such as insurance companies and pension funds, which also hold large portfolios of financial assets that are insured or otherwise supported by the firms obtaining taxpayer support. Ordinary bankruptcy proceedings can tie assets up for years and leave creditors and large depositors with significant cash-flow problems. On the other hand, if the values of mortgage-backed securities do not recover, the "capital injections" simply postpone the adjustments that eventually will have to be made. The primary beneficiaries in that case are the employees in the financial sector, who continue to earn relatively large salaries as shareholder prices fall to zero.

The cost-effectiveness of the preferred share purchase program also depends on a variety of other policy decisions that affect financial markets and the macro economy. It bears noting that the fundamental problems of weak markets for both prime and sub-prime mortgagebacked securities would have been addressed by the original asset purchase plan and by the asset insurance program placed in the House and Senate bill by the Republicans. There is an opportunity cost for the money devoted to preferred share purchases. Capital injections in a relatively small subset of undercapitalized firms (mostly banks) do not provide much help for most non-recipient firms.

At the same time that fundamental problems are not addressed, new risks are being introduced. (1) The preferred shares functionally are very similar to "negative equity" loans on which interest rates jump after a few years, leaving borrowers with much larger payments to make in financial circumstances that may not be radically better. This will increase risks in the financial sector when the higher payments begin, unless the firms return to financial health by then. The housing bubble, however, is not likely to rapidly re-inflate to its peak value, nor are the associated bubbles in credit-backed securities and stocks. The values of MBSs will be more accurately assessed by the time the higher interest payments have to be paid, but it is not clear how much they will increase in value after the panic is over. ${ }^{53}$ (2) Preferred share purchases reduce the rewards earned by more prudent firms in the financial industry, while creating a major moral hazard problem for large firms that are "too big to fail" that will have to be addressed through future regulations.

(3) Additional system-wide and macroeconomic risks are being introduced by selling so many government bonds in a short period of time. Borrowing $\$ 1.7$ trillion ( $\$ 250$ billion

\footnotetext{
${ }^{53}$ It bears noting that major components of most mortgage-backed securities are still very safe and even subprime mortgages and their derivatives are reasonably secure (in the medium run), because most borrowers continue to make their mortgage payments and their mortgages are backed by the values of the houses against which the loans were taken. House prices have fallen and are often now below those of the loans they support, but they have, on average, fallen by $20 \%$, rather than $80 \%$ of their peak value. The asset value of a house, however, is only the final guarantee of mortgage-backed securities. The riskier foundations of subordinate mortgage-backed securities imply that the true market value of those securities has fallen much further than house prices in the present economic conditions.
} 
deficit $+\$ 700$ billion bailout $+\$ 800$ billion stimulus package of early 2009) requires by far the largest one-year issue of government debt ever, and proportionally the largest since World War II. The previous post-war record for nominal debt issue was $\$ 412$ billion in 2004. The sale of so many government bonds allow investors to more easily flee the stock, bond, and real estate sectors in the short run, which tends to exacerbate the credit crisis being addressed. In the medium run, the sale of so much new debt is likely to have interest rate effects that make borrowing more costly for the private sector, while putting downward pressure on the dollar in world currency markets. ${ }^{54}$ (4) In the medium to long run, economic recovery will tend to increase interest rates on government debt, as investors return to private securities, reinforcing the structural deficit problems associated with its long term Social Security and Medicare commitments.

In spite of such problems, President Bush requested the second half of the TARP funds (at President-elect Obama's request) on January 12, 2009, and President Obama signed a new $\$ 780$ billion dollar stimulus package into law on February 17, 2009. ${ }^{55}$

\subsection{Lessons for constitutional political economy: On the value and limitations of standing policies (and policy revisions during crises)}

The responses of the Congress and Department of Treasury illustrate the difficulties of effective crisis management. The results to date also shed light on the advantages and disadvantages of using standing institutions and authority to deal with business cycles and constrain financial market risk-taking.

On the one hand, the problems were magnified by long-standing quasi-government institutions and policies that attempted to subsidize homeownership for the middle class and poor, although the proximate cause was largely produced by a series of agency problems within and among private firms. ${ }^{56}$ On the other hand, the most ambitious efforts to address the financial and macroeconomic problems associated with a sudden $20 \%$ decline in national wealth were undertaken by the Federal Reserve System. ${ }^{57}$

The Federal Reserve Bank has used its discretion to adopt a variety of policies, well beyond its routine open market operations and control of the Federal funds rate. For the most part, these policies have been similar to, but substantially broader than, its normal open market operations. For example, the Fed has accepted a variety of AAA-backed securities

\footnotetext{
${ }^{54}$ This paper focuses on the microeconomic issues, but if Ricardian equivalency is taken seriously, taxpayers may also realize that their future tax obligations have been increased as a consequence of the debt issue, and will reduce their current consumption to put money aside for their future tax increases (Barro 1974). Many macroeconomists believe that increases in government debt (e.g., deficits) have little or no short-run effects on economic growth and a negative one in the long run.

${ }^{55}$ Congress did not block the release of those funds, and so $\$ 350$ billion of additional funds became available to Treasury 15 days later.

${ }^{56}$ Congressional testimony suggests that many mortgage originators exaggerated the quality of their mortgages, that the private rating companies underestimated those risks and subsequent risks of mortgage-backed securities. These resulting over-assessments of the values of the mortgage-backed securities generated the great "meltdown" of portfolios grounded in those securities as housing prices fell. Jenkinson (2008) argues that the lack of transparency in risk assessments as well as some of the techniques used made it difficult for others to double-check their assessments and reduced the accuracy of risk appraisals in a manner that was difficult for outsiders to know. Evidently, too, many investors trusted other persons in the market to do their risk assessment(s) for them.

${ }^{57}$ For an overview of Federal Reserve actions through January 2009, see Bernanke (2009).
} 


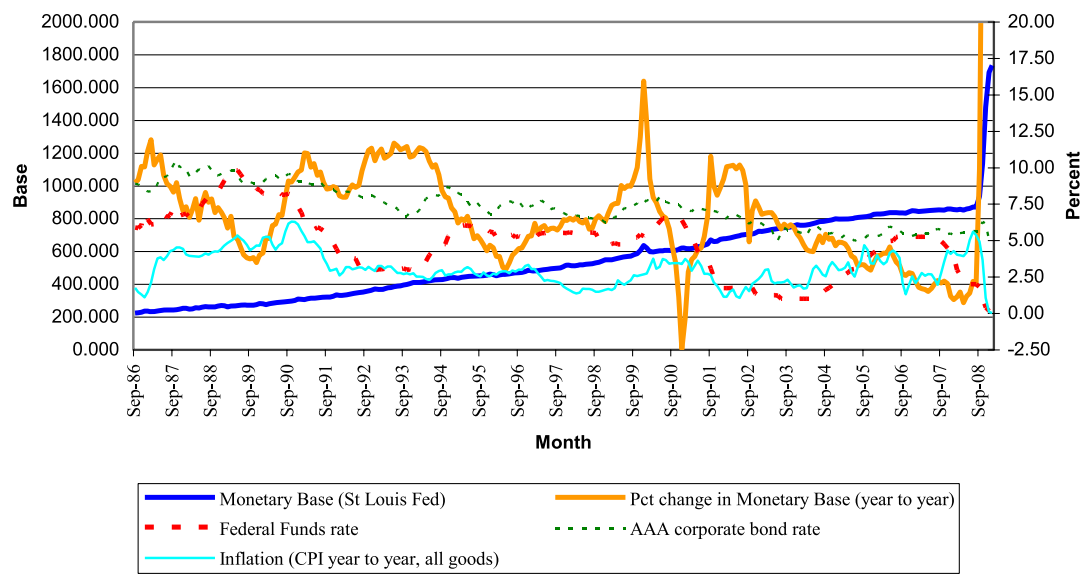

Fig. 8 Federal Reserve policies: Monetary base, year-to-year percentage change, and federal funds rate (monthly) 1986-2009

as collateral for loans (of dollars) and initiated its own TARP-like program for mortgagebacked securities at the New York Federal Reserve Bank (on January 5, 2009), when it began purchasing mortgage-backed-securities guaranteed by Fannie Mae and Freddie Mac. ${ }^{58}$ During the second half of 2008 the Federal Reserve tripled its reserves by acquiring approximately $\$ 1.4$ trillion of additional financial assets through open market operations and through the acceptance of new forms of collateral for short-term loans (Domestic Open Market Operations During 2008, FRB-NY, chart 2). As a consequence of these and related actions, the monetary base has effectively doubled from November 2008 through January 2009 (see Fig. 8).

The credit crisis consequently has been far milder in the banking sector than in the nonbanking financial sector. Commercial credit by all commercial banks rose from $\$ 9.2$ trillion to $\$ 9.9$ trillion through 2008 , with only a minor month-to-month declines in the last few months of 2008. Interest rates on AAA commercial bonds remained in their historically low 5-6\% range for 2008 (except in November). Interest rates on BAA bonds, however, rose by about $2 \%$ in the last few months of 2008 (from 6.5\% to 8.4\%), which suggests that credit risks are being more stringently priced; the new rates are not however higher than in past decades (see Fig. 5).

\footnotetext{
${ }^{58}$ Relatively safe mortgage-backed securities are evidently being bought as open market operations, and a relatively high price has been paid for the first purchases of insured mortgages ( $F R B-N Y F A Q$, December 3, 2008). As of February 4, 2009, the New York Federal Reserve Bank held $\$ 29.9$ billion (par) of Fannie Mae, Freddie Mac, and FHLB mortgage-backed securities. By April 1, the Fed had purchased 236 billion dollars of Mortgage Backed Securities (see the FRB-NY's System Open Market Account Holdings). Government support for GSE securities is indicated in the Treasury's press release of November 12, 2008, which states that: "Eight weeks ago, Treasury took responsibility for supporting the agency debt securities and the agency MBS through a preferred stock purchase agreement that guarantees a positive net worth in each enterpriseeffectively, a guarantee on GSE debt and agency MBS. We also established a credit facility to provide the GSEs the strongest possible liquidity backstop. As the enterprises go through this difficult housing correction we will, as needed and promised, purchase preferred shares under the terms of that agreement. The U.S. government honors its commitments, and investors can bank on it."
} 


\section{Political and economic conclusions and suggestions}

Given a perceived crisis, the U.S. government responds rapidly with policies that are largely consistent with public choice predictions. Voter concerns (and expected concerns) induce congressional and presidential action. The bureaucracy, in turn, makes use of its bargaining power to secure discretion over resources, while addressing the perceived problems of the day. Crisis management, however, remains as problematic as ever, because decisions must be made quickly in poorly informed circumstances.

Much of the data associated with the recession of 2008, however, suggests that the term "crisis" was overused in mid-2008, although that term did trigger rapid, although not necessarily well-considered, responses from government. The first year of the present recession was caused by routine responses of consumers to wealth reductions associated with the end of the real estate and stock bubbles, and by the usual adjustment of firms to reduced consumer demand. Two of the three major U.S. markets for credit performed more or less normally. Moreover, much of the policy response also has been fairly routine. The Federal Reserve reduced interest rates and expanded the monetary base. Congress extended benefits for the unemployed and increased government spending (and deficits). Many bank failures were addressed by the FDIC through mergers, some of which were subsidized with FDIC reserves.

The collapse of the asset-backed securities segment of the credit market could, however, have been termed a crisis. It was largely unexpected, because risks associated with mortgage-backed securities had been underestimated and underpriced, and a variety of regulatory and agency problems had been neglected. As markets repriced the risks associated with mortgage-backed securities, the balance sheets of a very broad range of financial institutions collapsed, threatening many with bankruptcy, and reduced flows of credit through non-bank channels. Ordinary bank and corporate bond markets provide substitutes for this source of credit, but increased credit flows through conventional channels have only partly offset the reduced credit flows from the securitized debt markets. Reductions in credit disrupt the finances of persons and firms that rely upon credit to increase their returns from their investments, as well as those who use credit for ordinary income smoothing and investment purposes. These credit-market effects tend to deepen the recession in a manner largely beyond most macroeconomic models. That is to say, they are large, unanticipated, "macroeconomic shocks."

The emergence of a huge market for mortgage-backed securities and their associated derivatives also introduced novel regulatory problems for which no standing policies were in place. Many of the laws and regulations that regulate capital reserves, assure transparency, and deal with bankruptcy for publicly traded firms did not apply (or could not easily be applied) to the new highly integrated international finance markets that emerged in the past two decades. Innovative regulatory and fiscal steps were taken to address this unexpected credit shock, but more remains to be done.

Reducing the likelihood of future global credit crises requires regulatory and risk assessment regimes that (1) take greater account of the internationalization of financial markets and their greater speed and interconnectedness, (2) produce greater transparency about the nature of the assets underlying various derivatives, about the size of these markets, and their capitalization, and (3) provide expedited bankruptcy proceedings for the financial sector that assure that assets of other firms (counter parties) are not entirely tied up for long periods of time (possibly with temporary loan facilities). The lack of transparency, together with the length of existing bankruptcy proceedings, tends to undermine trust and encourage panic within the financial services industry during times of increased uncertainty. Markets cannot 
do their information-aggregating magic, unless at least reasonably complete and unbiased information is available for the assets traded. Even honest "insiders" cannot do it all.

The crisis in high finance also implies that some more aggressive application of antitrust law in the financial sector should be contemplated for the future. When a few large firms with poor management or mistaken theories can cause the world's entire financial system to become dysfunctional, it is prudent to diversify "our" portfolio of managers by shrinking the average size and increasing the number of financial firms. (Many investment firms also evidently need better internal regulation and incentive structures. Both high rollers and the winner's curse can evidently ruin great financial firms.) More stringent capital requirements would also help mitigate this problem, especially for large firms, but the value of risky assets is always difficult to value precisely.

The experience of 2008 also reveals the limits of existing institutions and laws that frame competition in credit markets. The standing rules and regulations that assure a good deal of transparency in "old-fashioned" stock and bond markets were not "upgraded" to assure equivalent transparency in the new financial markets that emerged in the 1990s. This allowed a good deal of financial innovation to take place, but with too many "trust" transactions taking place, without sufficient independent verifications of the associated risks (Jenkinson 2008).

The creation and use of large players in the mortgage markets to subsidize low-income housing also increased the fragility of the market for mortgage-backed securities. These policies indirectly induced more and more risky mortgages and mortgage-backed securities to be produced, because the assets were implicitly insured by taxpayers through implicit off-budget guarantees for Fannie and Freddie's commitments, but without much oversight or review. The indirect consequences of these long-standing policies will cost U.S. taxpayers more than a trillion dollars. Shifting government promises "off budget" also increases fiscal illusion by making their costs more difficult to assess. Unfortunately, this lack of transparency seems to be the purpose of providing so many government guarantees off-budget.

Most of us would be better off if there were a standing, systematic method of accounting for and reporting off-budget obligations, as has proven to be the case for firms in private markets (after Enron). Auditing the long-term fiscal responsibilities of the Federal government could be added to the General Accounting Office's and Congressional Budget Office's lists of responsibilities. Some institutionalized method of formally reviewing long-term policies that expose taxpayers to major risks would also be useful, so that policies can be revised in the light of day without the urgency and errors of a genuine crisis. (An outward looking system-wide risk assessing agency would be unlikely to notice or to address the internal problems produced by government programs. ${ }^{59}$ )

In addition to improvements in standing procedures for regulating financial markets and review of government programs, improvements in economic theory also seem necessary. First, it seems clear that efficient market theory needs to be modified somewhat. Even wellinformed traders and markets evidently can make major systematic mistakes in appraising the risk of complex financial assets in an uncertain world. Moreover, a good deal of evidence demonstrates that firms and markets have not fully solved their various principal-agent problems, which may partly explain why so many large diversified financial firms performed less

\footnotetext{
${ }^{59}$ Recent in favor of a system-wide risk regulator ignore the fact that analysts nearly always disagree about macroeconomic and regulatory risks. Very few experts saw the financial crisis coming-which of course is why there was a crisis. Regardless of whether optimists, pessimists, or moderates were in charge, such an agency would tend create new risks by over-weighting one group of forecasters or another. (It would, however, be useful to have additional research about the existence of such macroeconomic and regulatory risks. That research would serve as "fire alarms" alerting the rest of us to possible risks.)
} 
well than smaller less diversified firms. All too many models assume that credit markets are perfect and that agency problems have been solved, or analyze only a subset of these related problems.

Many macroeconomists tend to think of credit as a monetary phenomena, because our financial system has been until recently grounded in "money-like" assets. The securitization of mortgages provided a new "real estate base" for credit, analogous to gold, which has outstripped the money-based banking system for the past 10 or 20 years as a source of new credit. The fall in real estate prices here and in several other places around the world has reduced the real-estate equivalent of the monetary base and induced a great reduction in the supply of credit constructed on that base. The Fed can directly control only the moneybased pool of credit, whose base has been expanding. Whether the Fed and Treasury can do enough to offset the credit multiplier effects in the real estate-based credit market and a $20 \%$ reduction in the financial wealth of Americans is not obvious, although forecasts for the end of the recession in late 2009 or early 2010 are hopeful. ${ }^{60}$ Whether the Fed can do so without generating significant inflation in a few years remains to be seen.

Acknowledgements Thanks are due to Alex Tabarrok, David Levy, Ilia Rainer, William Shughart, and Stan Winer for helpful conversations, suggestions, and critiques.

\section{References}

Abraham, J. M., \& Hendershott, P. H. (1994). Bubbles in metropolitan housing markets. Journal of Housing Research, 7, 191-209.

Fannie Mae (2006). Annual Report, Washington DC.

Fannie Mae (2007). Annual report, Washington DC.

Freddie Mac (2007). Annual Report, Washington DC.

Bajaj, V., \& Labaton, S. (2009). Big risks for U.S. in trying to value bad bank assets. New York Times (February 1). Available at: http://www.nytimes.com/2009/02/02/business/economy/02value.html?_r=1.

Barro, R. J. (1974). Are government bonds net wealth? Journal of Political Economy, 82, 1095-1117.

Bernanke, B. S. (2008). Mortgage delinquencies and foreclosures. Speech at Columbia Business School (May 5). Available at: www.federalreserve.gov/newsevents/speech/Bernanke20080505a.htm\#f2.

Bernanke, B. S. (2009). Federal Reserve programs to strengthen credit markets and the economy. Testimony before the House Committee on Financial Services, U.S. House of Representatives (February 10). Available at: federalrserve.gov/newsevents/testimony/bernanke20090210a.htm.

Breton, A., \& Wintrobe, R. (1975). The equilibrium size of a budget-maximizing bureau: a note on Niskanen's theory of bureaucracy. Journal of Political Economy, 83 195-207.

Capozza, D. R., \& Seguin, P. J. (1994). Expectations, efficiency, and euphoria in the housing market. Regional Science and Urban Economics, 26, 369-386.

Case, K. E., \& Shiller, R. J. (1989). The efficiency of the market for single family homes. American Economic Review, 79, 125-137.

Case, K. E., \& Shiller, R. J. (2003). Is there a bubble in the housing market? Cowles foundation paper 1089, Yale University.

Case, K. E., Quigley, J. M., \& Shiller, R. J. (2001). Comparing wealth effects: the stock market versus the housing market. Cowles Foundation Discussion Paper No. 1335, Yale University.

Cecchetti, S. G. (2008). Measuring the macroeconomic risks posed by asset price booms. In J. Y. Cambell (Ed.), Asset prices and monetary policy (pp. 9-34). Chicago: University of Chicago Press.

Chari, V. V., Christiano, L., \& Kehoe, P. J. (2008). Facts and myths about the financial crisis of 2008. Federal Reserve Bank of Minneapolis, Working Paper 666 (October). Available at: www.minneapolisfed.org/research/WP/WP666.pdf.

Crippen, D. L. (2001a). Federal subsidies and the housing GSEs. Congressional Budget Office Report, Washington. Available at: www.cbo.gov/ftpdocs/28xx/doc2841/GSEs.pdf.

\footnotetext{
${ }^{60}$ The lower capital requirements for the real estate-based credit sector implies a larger credit-multiplier than that of the commercial banking sector.
} 
Crippen, D. L. (2001b). Federal subsidies for the housing GSEs. Testimony before the Subcommittee on Capital Markets, U.S. House of Representatives. Available at: www.cbo.gov/doc.cfm?index=2839\&type=0.

Congleton, R. D. (2005). Toward a political economy of crisis management: rational choice, ignorance, and haste in political decision making. Dynamics of Intervention, Advances in Austrian Economics, 8, 183204

Cowan, C. L. (2003). History and overview of securitization. Testimony before the housing and community opportunity subcommittee on financial institutions and consumer credit. U.S. House of Representatives (November 5).

Day, K. (2006). Study finds 'extensive' fraud at Fannie Mae. Washington Post (May 24), A01.

Dickerson, C. H. (2004). Report of findings to date, special examination of Fannie Mae. Office of Federal Housing Enterprise Oversight, Washington DC.

Gjerstad, S., \& Smith, V. L. (2009). From bubble to depression. Wall Street Journal (April 6), A15.

Gramlich, E. M. (2000). Predatory lending practices. Testimony before the Committee on Banking and Financial Services, U.S. House of Representatives (May 24).

Greenspan, A. (2003). Corporate governance. Speech at the 2003 conference on bank structure and competition, Chicago Illinois (May 8). Available at: http://www.federalreserve.gov/boarddocs/speeches/2003/ 20030508/default.htm.

Greenspan, A. (2004). Government-sponsored enterprises. Testimony before the U.S. Senate Committee on Banking, Housing and Urban Affairs (February 24). Available at: http://www.federalreserve.gov/ boarddocs/testimony/2004/20040224/default.htm.

General Accounting Office Report to the Congress (July 1996). Financial audit: Resolution trust corporation's 1995 and 1994 financial statements. Washington DC. Available at: http://www.gao.gov/archive/ 1996/ai96123.pdf.

Higgs, R. (1987). Crisis and leviathan. Oxford: Oxford University Press.

Himmelberg, C. P., Mayer, C. J., \& Sinai, T. M. (2004). Assessing high house prices: bubbles, fundamentals, and misperceptions. Federal Reserve Board Staff Report 218.

Historical census of housing tables: home ownership, (2004). U.S. Bureau of the Census, Washington DC. Available at: http://www.census.gov/hhes/www/housing/census/historic/owner.html.

Irwin, N., \& Cho, D. (2008). U.S. offers citigroup expansive safety net. Washington Post (November 24$)$, A01. Available at: www.washingtonpost.com/wpdyn/content/article/2008/11/23/AR2008112301665.html.

Jenkinson, N. (2008). Ratings in structured finance: what went wrong and what can be done to address shortcomings? CGFS Papers 32. Basel, Switzerland: Committee on the Global Financial System.

Kennickell, A. B. (2006). Currents and undercurrents: changes in the distribution of wealth 1989-2004. Washington DC: Federal Reserve Board Report (August 2).

Labaton, S. (2008). Agency's '04 rule lets banks pile up new debt. New York Times (October 3). Available at: http://www.nytimes.com/2008/10/03/business/03sec.html?_r=2\&sq=fi.

Lei, V., Noussair, C. N., \& Plott, C. R. (2001). Nonspeculative bubbles in experimental asset markets: lack of common knowledge of rationality vs. actual irrationality. Econometrica, 69, 831-859.

Malpezzi, S. (1999). A simple error correction model of housing prices. Journal of Housing Economics, 8, $27-62$.

Mason, D. L. (2004). From buildings and loans to bail outs: A history of the American savings and loan industry, 1831-1995. Cambridge: Cambridge University Press.

Mason, J. R., \& Rosner, J. (2007). How resilient are mortgage-backed securities to collateralized debt obligation market disruptions? Social Science Research Network (SSRN) working paper 1027472.

Merced, M. J., \& Story, L. (2009). Nearly 700 at Merrill in million-dollar club. New York Times (February 11). Available at: www.nytimes.com/2009/02/12/business $/ 12$ merrill.html? scp=2\&sq=bonuses\&st=cse.

Miller, M. H., \& Modigliani, F. (1961). Dividend policy, growth, and the valuation of shares. Journal of Business, 34, 411-433.

Niskanen, W. A. (1971). Bureaucracy and representative government. Chicago: Aldine, Atherton.

Olson, M. (1965). Logic of collective action: public goods and the theory of groups. Cambridge MA: Harvard University Press.

Stanton, R. (1995). Rational prepayment and the valuation of mortgage-backed securities. Review of Financial Studies, 8, 677-708.

Stigler, G. J. (1971). The theory of economic regulation. Bell Journal of Economics and Management Science, 3, 3-18

System Open Market Account Holdings. Federal Reserve Bank of New York. Available at: http://www. newyorkfed.org/markets/soma/sysopen_accholdings.html.

Yellen, J. (2005). Housing bubbles and monetary policy. Speech, October 21. Federal Reserve Bank of San Francisco.

U.S. Treasury International Capital System Report on Foreign Portfolio Holdings of U.S. Securities, Department of Housing and Urban Development report (May 2007). Washington DC. Available at: www.hud.gov/content/releases/07-072table.pdf. 